\title{
Making Fiscal Space Happen: Managing Fiscal Policy in a World of Scaled-Up Aid
}

\author{
Peter S. Heller, Menachem Katz, \\ Xavier Debrun, Theo Thomas, \\ Taline Koranchelian, and Isabell Adenauer
}





\title{
IMF Working Paper
}

Fiscal Affairs Department

\section{Making Fiscal Space Happen: Managing Fiscal Policy in a World of Scaled-Up Aid}

Prepared by Peter S. Heller, Menachem Katz, Xavier Debrun, Theo Thomas, Taline Koranchelian, and Isabell Adenauer

Authorized for distribution by Peter S. Heller

December 2006

\begin{abstract}
This Working Paper should not be reported as representing the views of the IMF. The views expressed in this Working Paper are those of the author(s) and do not necessarily represent those of the IMF or IMF policy. Working Papers describe research in progress by the author(s) and are published to elicit comments and to further debate.

Debt relief and the scaling up of aid to low-income countries should allow for greater fiscal space for expenditure programs to create long-term growth and lower poverty rates. But designing a suitable medium-term fiscal framework that fosters a sustainable delivery of better public services and infrastructure while maintaining a credible commitment to fiscal prudence confronts many challenges. This paper discusses what low-income countries can do to shape fiscal policy frameworks that are ambitious in trying to absorb additional aid while still ensuring longer-term sustainability for government expenditure programs and finances. It suggests what approaches can be used to manage the greater fiscal policy risks associated with a scaled-up aid environment, including coordination with monetary policy. The paper also discusses what institutional changes are needed if donors and countries are to facilitate the implementation of a higher level of aid-financed spending programs.
\end{abstract}

JEL Classification Numbers:O11; O23; H39

Keywords: Aid; fiscal policy; low-income countries; macroeconomic policy; public financial management

Authors’e-mail addresses: pheller@imf.org,mkatz@imf.org, xdebrun@imf.org, thomas@imf.org, tkoranchelian@imf.org, iadenauer@imf.org 


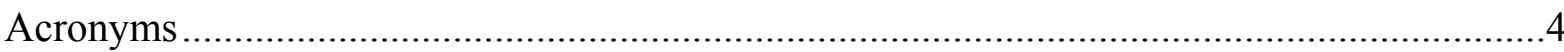

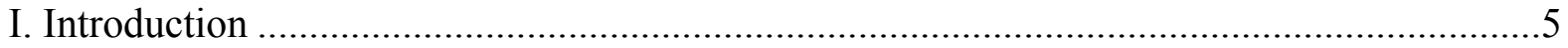

II. Setting the Appropriate Fiscal Policy Framework .....................................................6

A. Towards a More Ambitious Medium-Term Fiscal Framework (MTFF).................6

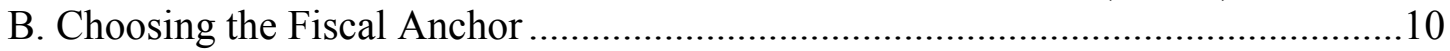

C. Fiscal, Monetary, and Exchange Rate Policy Coordination..................................16

III. Enhancing the Management of Fiscal Risk ............................................................21

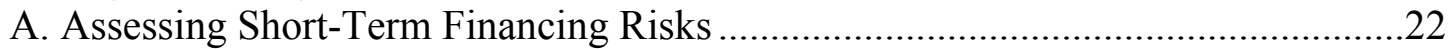

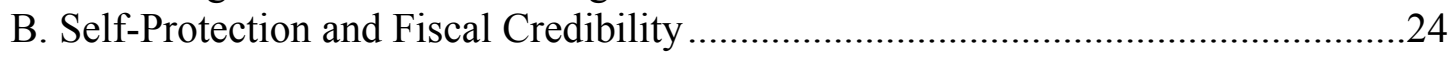

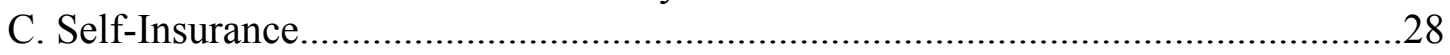

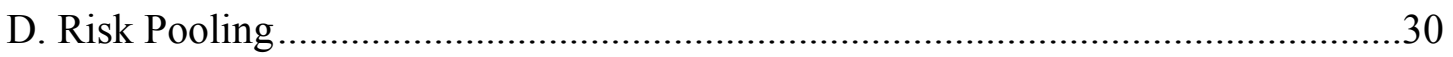

IV. Institutional Approaches to Facilitate Fiscal Management with Scaled-Up Aid Flows....31

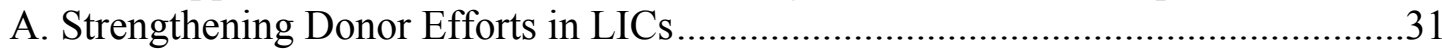

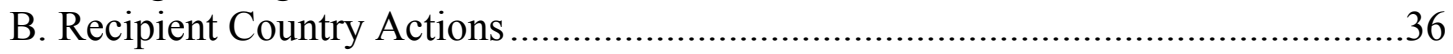

C. Strengthening the Medium-Term Fiscal Orientation ........................................ 38

D. Strengthening the Institutional Mechanisms for Monetary and Fiscal

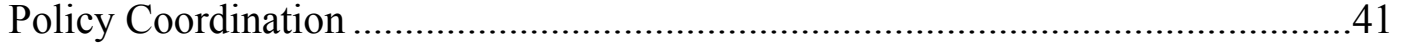

E. Independent Audits of the Fiscal Policy Framework .......................................41

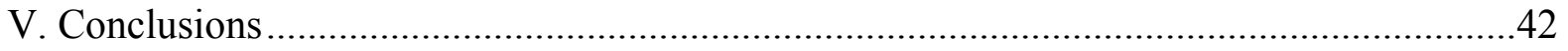

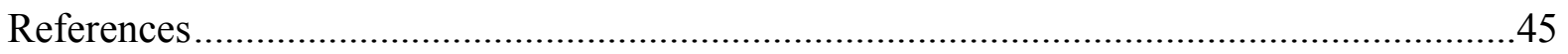

Tables

1. Sample Liquidity Indicators for Scaled-Up Aid

Figures

1. Ethiopia: Stress Tests on Public Sector Grants (2005-2016) .........................................49

2. Ethiopia: Risks Related to Grant Volatility (2005-2016) .............................................51

3. Ethiopia: Hypothetical Effect of Alternative Reserve Policies.......................................53

Boxes

1. Reconciling Fiscal Rules in a Currency Union with Scaled-Up Aid: The WAEMU Case .20

2. Ring Fencing of Priority Expenditures: Uganda's Poverty Action Fund (PAF) ................27

3. Developing Long-Term Partnerships: The U.K. Experience ..........................................33

4. The Impact of Donor Coordination on Aid Management: Tanzania's Experience .............34

5. The Benefits of Donor Coordination: The Case of Burkina Faso ....................................35

6. Managing and Accounting for Aid Not Channeled through the Budget ............................37

7. Ghana: The Medium-Term Expenditure Framework .................................................40 
Charts

1. IMF Projections for External Grants: 2006 and 2008

2. Alternative MTFF Financing Paths .......................................................................... 9

Appendix

Ethiopia:Assessing the Risks from Revenue Volatility under Scaled-Up Aid ......................48 


\section{ACRONYMS}

\begin{tabular}{|c|c|}
\hline AAP & Assessment and Action Plan \\
\hline AfDB & African Development Bank \\
\hline CAR & Cost-at-risk \\
\hline DFID & United Kingdom Department for Financing International Development \\
\hline DSA & Development Sustainability Assessment \\
\hline DSF & Development Sustainability Framework \\
\hline G8 & Group of Eight \\
\hline HIPC & Highly Indebted Poor Country \\
\hline JAS & Joint Assistance Strategy \\
\hline LIC & Low-income country \\
\hline MDGs & Millenium Development Goals \\
\hline MDRI & Multilateral Debt Relief Initiative \\
\hline MTBF & Medium-Term Budgetary Framework \\
\hline MTEF & Medium-Term Expenditure Framework \\
\hline MTFF & Medium-Term Fiscal Framework \\
\hline NPV & Net present value \\
\hline O\&M & Operations and maintenance \\
\hline ODA & Official development assistance \\
\hline $\mathrm{OECD}$ & Organisation for Economic Co-operation and Development \\
\hline $\mathrm{OECD} / \mathrm{DAC}$ & OECD Development Assistance Committee \\
\hline PAF & Policy Assessment Framework \\
\hline PEAP & Poverty Eradication Action Plan \\
\hline PEFA & Public Expenditure and Financial Accountability \\
\hline PFM & Public Financial Management \\
\hline PRBS & Poverty Reduction Budget Support \\
\hline PRGF & Poverty Reduction and Growth Facility of IMF \\
\hline PRS & Poverty Reduction Strategy \\
\hline PRSP & Poverty Reduction Strategy Paper \\
\hline TAS & Tanzania Assistance Strategy \\
\hline TRA & Tanzania Revenue Authority \\
\hline VAT & Value added tax \\
\hline WAEMU & West African Economic and Monetary Union \\
\hline
\end{tabular}




\section{INTRODUCTION}

For many low-income countries (LICs), the commitment of the Group of Eight (G8) to double aid flows by 2010 offers the prospect of a substantial expansion in the share of their budget financed from external sources. Some increase in fiscal space has already emerged from the Multilateral Debt Relief Initiative (MDRI), freeing resources previously used for debt service. Part of the increase in aid will undoubtedly come in the form of general budget or sectoral support. Other increases may come from support for specific projects or programs.

Managing these inflows can pose important challenges for governments seeking to exploit the potential for greater fiscal space (Heller, 2005a, 2005b). Though a substantial increase in flows has still not materialized, it is valuable to consider, in anticipation, how governments should respond to such challenges as:

- $\quad$ Realizing a spending path aimed at the Millennium Development Goals (MDGs): Countries are being urged to mount ambitious spending programs to achieve the MDGs. Yet the financing gap between needs and potential aid commitments still seems large and donor priorities often emphasize expenditure programs to which LIC governments assign a low priority in terms of achieving the MDGs. Given this prospective financing gap and differing expenditure priorities, how much should governments scale up their spending programs?

- Determining how much to borrow: The MDRI has reduced external debts, leading some countries to consider borrowing for infrastructure investments. What factors should influence the decision to borrow?

- Managing the transition path to self-reliance: How can LICs ultimately graduate from dependency on aid while still maintaining scaled-up expenditure programs?

- How to coordinate monetary, fiscal, and exchange rate policies in order to absorb higher aid and neutralize the impact of aid volatility, while still maintaining macroeconomic stability?

- How can governments limit the risks associated with the greater reliance on external assistance in the financing of social service programs (particularly for HIV/AIDS treatment)? Such programs additionally may be difficult to curtail in the event of aid shortfalls. Should governments expand their spending programs in spite of the limited time frame over which donors make aid commitments? Are there potential risks in expanding expenditure programs associated with reliance on grant finances that are not long term in nature?

The challenge of exploiting effectively the potential for additional fiscal space has to be shared between donors and LICs. Actions by donors in terms of increased predictability, 
harmonization, and alignment can make the task of LIC decision makers easier and less costly. But LICs still must consider how to tailor their fiscal policies to respond to the challenges of scaled-up aid and how to strengthen their fiscal institutions to manage higher spending programs.

This paper offers a perspective on how LICs and the donor community can address these challenges. Section II considers how LICs should manage fiscal policy in a scaled-up aid environment, including issues of fiscal, monetary, and exchange rate policy coordination. Section III examines approaches to fiscal risk management. Section IV analyzes how a strengthening of institutions can facilitate fiscal policy formulation in a high aid environment, and Section V offers concluding thoughts.

\section{Setting the Appropriate Fiscal Policy Framework}

\section{A. Towards a More Ambitious Medium-Term Fiscal Framework (MTFF)}

The HIPC initiative encouraged countries to formulate Poverty Reduction Strategy Papers (PRSPs) - detailed multi-year, multi-sectoral strategies to raise growth and meet the MDGs. Countries were expected to formulate an MTFF to map out the key fiscal targets guiding budgetary policy in the current fiscal year, with some perspective on the budget in subsequent years. The criteria for a well-formulated MTFF would include:

- Consistency with a government's policy objectives, which presumably include the achievement of rapid economic growth and progress toward the achievement of the MDGs, taking account of the potential feedback effects of different spending programs on the growth rate.

- Macroeconomic and fiscal sustainability, meaning that the overall expenditure program is consistent both with a stable and growth-promoting macroeconomic policy framework and with a sustainable financial position for the government over the medium to long term.

- Budget sustainability over the medium term so as to facilitate a smooth and wellsequenced expenditure path, particularly for social sector programs, taking account of the operations and maintenance (O\&M) implications of new investments.

- Comprehensiveness in terms of inclusion of all elements of a government's fiscal program, including not only immediate revenue and expenditures but also potential fiscal commitments and guarantees.

- Strengthened domestic revenue performance that promotes eventual graduation from aid dependency.

The difficulty for countries is to reconcile the desire for ambitious spending programs with the reality that total aid to a country remains insufficient and that few donors can make long- 
term commitments of aid. Hard commitments by donors for the out-years of the budget horizon typically diminish. In order to ensure a manageable debt position and minimize exposure to risk, governments have adopted a conservative posture (usually endorsed in IMF-supported programs) as to the pace at which the overall budget would expand.

With the recent infusion of increased aid in some social sectors (particularly for health) and the prospect of a further expansion of aid, LICs are now being urged to mount ambitious spending programs that require financing beyond immediate aid commitments. Jeffrey Sachs in particular has called on the IMF and the World Bank to work with countries to develop and cost comprehensive strategies to achieve the MDGs. ${ }^{1}$ Such "needs-based" strategies would illuminate the "financing gap" to be filled by the donor community by 2015 in order to realize the MDGs. Sachs equally argues that the IMF should support governments by using an MTFF consistent with a needs-based MDG scenario.

In this new aid environment, fault can be found with both the strategy advocated by Sachs and the approach traditionally used by countries in the context of IMF-supported programs. The Sachs approach is useful for advocacy purposes, clarifying the financing needed to reach the MDGs. But for the operational programming of fiscal policy, a government's spending programs in individual sectors must be based on relatively firm expectations that financing will indeed be available. In contrast, the "realistic" IMF approach, which involves only taking account of hard financing commitments by donors, can be criticized as not taking account of a prospective global environment of enhanced aid. Some sense of the extent to which this may be an issue can be obtained from Chart 1, which examines forward-looking IMF projections for the period 2006-08 of external grants. In a substantial proportion of the countries surveyed, grant levels are projected to fall. ${ }^{2}$ Relying only on hard commitments will always tilt against an expansion in capacity, especially in social sector programs. This is particularly problematic for aid that finances vertical disease programs, where sustainable financing is critical.

\footnotetext{
${ }^{1}$ This appeal was ratified at the UN General Assembly in the fall of 2005, which called on LICs to put together comprehensive MDG-based strategies.

${ }^{2}$ Of course, there may be multiple reasons why the IMF projects the primary deficit to rise and fall, independent of the impact of additional aid flows.
} 


\section{Chart 1. IMF Projections for External Grants: 2006 and 2008}

(as a percent of GDP)

\begin{tabular}{|c|c|c|}
\hline $\begin{array}{l}\text { Countries where projections indicate } \\
\text { reduced grant share between } 2006 \\
\text { and } 2008\end{array}$ & $\begin{array}{l}\text { Countries where projections indicate } \\
\text { an expanded grant share between } \\
2006 \text { and } 2008\end{array}$ & $\begin{array}{l}\text { Countries where no change is } \\
\text { projected between } 2006 \\
\text { and } 2008\end{array}$ \\
\hline $\begin{array}{l}\text { Africa } \\
\text { Bourkina Faso } 2.7 \rightarrow 0.9 \\
\text { Burundi } 23.7 \rightarrow 20.2 \\
\text { Cameroon } 0.4 \rightarrow-0.2 \\
\text { Congo D.R. C. } 10.4 \rightarrow 7.6 \\
\text { Guinea } 0.8 \rightarrow 0.3 \\
\text { Guinea-Bissau } 5.9 \rightarrow 5.5 \\
\text { Madagascar } 1.6 \rightarrow 1.1 \\
\text { Malawi } 13.5 \rightarrow 11.4 \\
\text { Mali } 1.4 \rightarrow-0.2 \\
\text { Mauritania } 2.0 \rightarrow 0.8 \\
\text { Mozambique } 6.2 \rightarrow 5.6 \\
\text { Niger } 3.8 \rightarrow 2.7 \\
\text { Senegal } 1.3 \rightarrow 1.1 \\
\text { Sierra Leone } 5.5 \rightarrow 4.5 \\
\text { Tanzania } 5.1 \rightarrow 4.7 \\
\text { Uganda } 7.4 \rightarrow 4.4 \\
\text { Other regions } \\
\text { Cambodia } 5.6 \rightarrow 5.0 \\
\text { Guyana } 6.4 \rightarrow 3.4 \\
\text { Honduras } 3.4 \rightarrow 3.1 \\
\text { Taiikistan }-14.9 \rightarrow-13.3\end{array}$ & $\begin{array}{l}\text { Africa } \\
\text { Chad } 1.9 \rightarrow 2.0 \\
\text { Ethiopia } 5.8 \rightarrow 7.6 \\
\text { The Gambia } 6.2 \rightarrow 10.7 \\
\text { Ghana } 3.8 \rightarrow 5.9 \\
\text { Rwanda } 12.1 \rightarrow 13.1 \\
\text { Zambia } 1.2 \rightarrow 1.3\end{array}$ & $\begin{array}{l}\text { Africa } \\
\text { Benin } \\
\text { Sao tome and Principe } \\
\text { Other regions } \\
\text { Nicaragua }\end{array}$ \\
\hline
\end{tabular}

Source: IMF (2006d) and internal IMF data.

Given that the major industrial nations have pledged an expansion in overall aid flows, should LICs assume that the external resources will indeed be forthcoming and that they should plan for expanded spending programs? If they do so, how should they balance the gains from a more ambitious scaling-up approach with the losses that would arise if the additional aid is not forthcoming? This paper advocates an MTFF that falls between the two camps. It advocates a more ambitious medium-term perspective than would typically be prescribed by the IMF in order to take advantage of the prospect of greater donor assistance. But it falls short of the Sachs approach, because the prospect of aid equivalent to that called for by a needs-based approach appears highly unlikely.

Such an "intermediate" MTFF scenario would allow for financing and expenditure to be smoothed over a multi-year horizon, and thus be aligned with priorities for addressing (if not actually reaching) the MDGs. ${ }^{3}$ It would help to guide efforts to expand absorptive capacity.

\footnotetext{
${ }^{3}$ Such a profile might entail significant upfront investments in infrastructure, say in the context of a wellformulated long-term strategy to realize the MDGs. The key is that governments ensure that the programmed expansion of expenditure takes place according to a prescribed path and is not exposed to a significant risk of abrupt adjustment.
} 
Such an MTFF would also recognize the need to ensure adequate consideration of the risks that such an approach entails, and the policies required to minimize them (see Section III).

This more ambitious MTFF would thus have country authorities projecting a medium-term financing scenario that is at the ambitious end of a realistic range of external financing possibilities. It would reflect that, although donor financing commitments rarely extend beyond two years, there is this strong G8 commitment for a new pro-aid environment. It would thus explore the implications of a level of external assistance in the out-years - of grants and concessional loans - as well as of nonconcessional borrowing - that is at least at the level budgeted for the current year (Scenario B) and most likely somewhat larger (Scenario C). Chart 2 recognizes that financing could be anywhere between lines $\mathrm{A}$ and $\mathrm{C}$ and requires a judgment call as to what is likely for a particular country, taking account of its relations with donor countries.

Financing

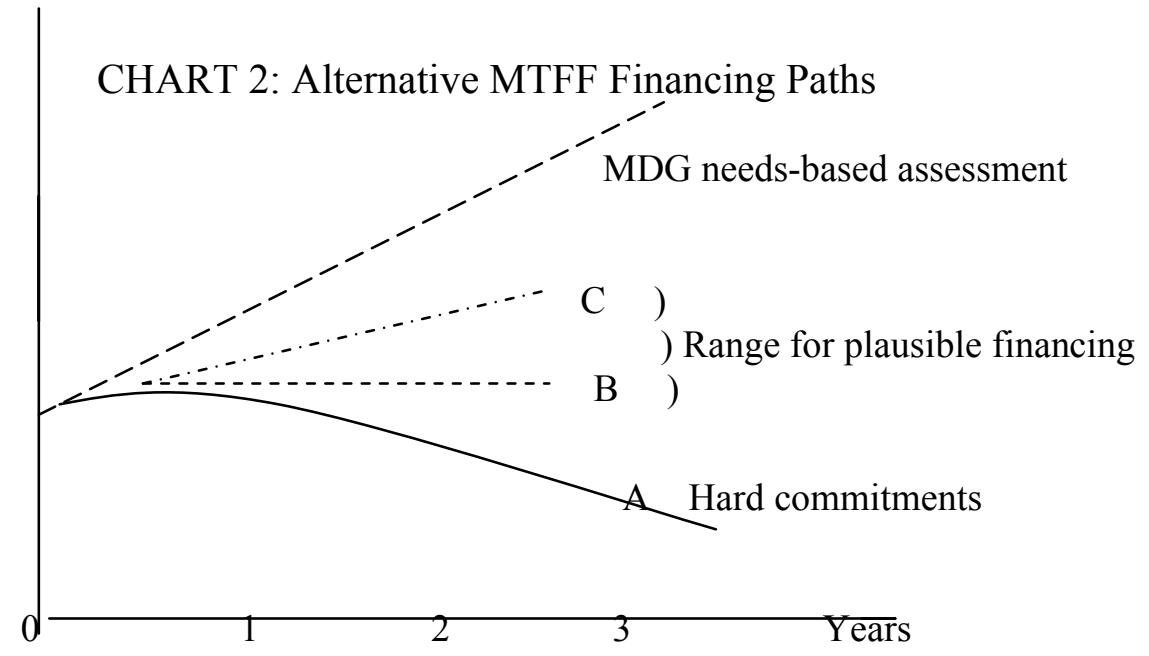

Such a framework would also be based on the presumption that domestic revenue shares not diminish. For countries with presently low ratios of tax and nontax revenues, they should rather be targeted to rise (see Section III.B below). ${ }^{4}$

In principle, designing such an alternative MTFF should not be difficult. ${ }^{5}$ Operationally however, a number of challenges would need to be faced in implementation. These include:

\footnotetext{
${ }^{4}$ It also assumes that a government will not implement domestic policies — abusive governance actions, largescale corruption in the use of aid, etc. - that "turn off" the tap of external assistance.

${ }^{5}$ An alternative approach might be to formulate the budget based on a conservative revenue and external resource projection, while nevertheless also formulating an alternative scenario to guide supplementary budgets and medium-term planning if available resources prove higher than prudently projected. Such a strategy has the advantage that it could reassure donors on the allocation of scaled-up budget support and allay concerns that the IFIs are not working with LICs on scaling-up scenarios. The downside to this approach is that it does not suggest how to address the uncertainty as to whether a higher flow of aid will be sustained beyond the next year or two.
} 
(i) the decision as to how ambitious the MTFF should be, taking account not only of what grants might be forthcoming but also how much domestic and external borrowing should be assumed; (ii) the need to formulate an expenditure program that is not only consistent with a country's growth and MDG aspirations but also aligned with donor priorities in a scaled-up aid environment; (iii) the need to address the possibility that a scaling up of aid flows may have adverse effects on a country's competitiveness; (iv) the level of risk to take on, given the possibility that donors will prove less generous than assumed or that higher aid may not substantially increase real growth rates; ${ }^{6}$ and (v) the gauging of a government's capacity to implement a scaled-up spending program. Ultimately, the specifics of a country's situation will determine where the MTFF should most appropriately be set.

\section{B. Choosing the Fiscal Anchor}

Underlying any operational approach to the management of fiscal policy is the choice of a credible fiscal anchor, ${ }^{7}$ viz., an approach for the setting of fiscal policy targets that ensures a sustainable and solvent fiscal policy, preferably over the longer term. Inter alia, a government could target the primary balance or the overall balance, exclusive or inclusive of grants. In practice, a good fiscal anchor is an institutional process that leads policymakers to implement fiscal adjustments whenever public debt threatens to reach levels that would be difficult to sustain without permanently high primary surpluses. ${ }^{8,9}$

\footnotetext{
${ }^{6}$ In particular, will a significant scaling up of aid be accompanied by diminishing returns (perhaps reflecting the weaker short- to medium-term growth impact of many social sector investments). A cautious approach would suggest that the real growth rate may not be substantially higher over the medium term. This is an issue also germane in any scenario analysis associated with debt sustainability assessments.

${ }^{7}$ More technically, the fiscal anchor is a mechanism (i.e., a set of constraints or an incentives scheme) to ensure that fiscal policy choices satisfy the intertemporal budget constraint so that there is no expectation of outright default or strategies akin to default—such as forced restructuring or a prohibitive inflation tax. The term "anchor" echoes the role of a nominal anchor as a precondition for price stability. For example, Bohn (1998) contends that an effective fiscal anchor is a policy that prescribes an increase in the primary fiscal balance in response to an increase in the level of public debt.

${ }^{8}$ In IMF (2003), the concern is expressed that, on average, emerging market countries stop responding to rising debt with higher primary surpluses once the debt exceeds 50 percent of GDP. Beyond that threshold, an average emerging market country is therefore likely to drift to an unsustainable path of debt accumulation.

${ }^{9}$ In principle, an array of institutional arrangements can provide such an anchor. They range from legally binding fiscal rules to formal commitments supported by strong accountability mechanisms or external incentives - such as those emanating from the conditionality of IMF-supported programs. Of course, the credibility and the effectiveness of these mechanisms ultimately rest on the costs (mainly reputational and political) incurred when they are ignored. In turn, these costs depend on the policymaker's perception of the budget constraint. Specifically, high debt levels make it difficult — and politically costly — to ignore the merits of adhering to a strict fiscal anchor, whereas low debt levels and large expenditure needs make it easy to downplay the importance of an anchor.
} 
For most LICs, the choice of a fiscal anchor has traditionally been dictated by the need to cope with high levels of external public debt and shallow domestic capital markets. The latter implies that if the government attempts to borrow too much, it is faced with a sharply higher borrowing rate, increasing the budgetary burden of debt service. This has led fiscal policymakers to set limits on new external borrowing, particularly of nonconcessional debt. In contrast, countries normally have felt free to accept grants to finance expenditure, since this has not raised debt sustainability issues.

One consequence of the recent MDRI has been to substantially relax the perceived financing constraint of LICs. By significantly reducing the ratio of the net present value (NPV) of debt to GDP, policymakers may now be less inhibited in their spending and borrowing decisions than in the past, thus weakening the importance of debt sustainability as a fiscal anchor. ${ }^{10}$ Countries may even believe that an increase in debt levels may trigger higher grant financing or enhanced concessionality in new loans (the so-called free rider problem), thus further weakening inhibitions against new borrowing. ${ }^{11}$ The consequence is that, at least in the short and possibly the medium term, the debt ceiling no longer provides an obvious "anchor" in determining the size of the expenditure envelope.

The issues thus arise as to how large the expenditure envelope should be, whether the expenditure target should be the fiscal anchor, and how much borrowing is acceptable in this new aid environment. A further consideration is whether the traditional acceptance of grantfinanced spending is appropriate or whether reliance on grants may pose unanticipated risks.

In the previous section, we suggested how to approach the issue of what to assume about how much external assistance - both grants and loans - would be received. We also argued that these external resources should be supplemented by a target for domestic revenue mobilization that calls for a gradually increasing domestic revenue ratio, comparable to countries of similar per capita income level. With one further assumption made as to the level of domestic borrowing (or deposit accumulation) that the government should program, one can then obtain an initial estimate for the outer limit of the target expenditure envelope, $\hat{\mathbf{E}}_{\mathbf{t}}$, for the MTFF. Specifically, the outer limit of expenditure in period $t, \hat{\mathbf{E}}_{\mathbf{t}}$, can be set at

$\hat{\mathbf{E}}_{\mathbf{t}}=\mathbf{E} \mathbf{o}_{\mathbf{t}}+\mathbf{E i}_{\mathbf{t}}=\mathbf{R}_{\mathbf{t}}+\mathbf{G t}_{\mathbf{t}}+\mathbf{B e}_{\mathbf{t}}+\mathbf{B d} \mathbf{d}_{\mathbf{t}}$ where

$\mathbf{E} \mathbf{o}_{\mathbf{t}}=$ primary (noninterest) expenditure,

$\mathbf{E i}_{\mathbf{t}}=$ interest expenditure,

$\mathbf{G t}_{\mathbf{t}}=$ the target for grants, and

$\mathbf{B e}_{\mathbf{t}}=$ the target for external borrowing,

\footnotetext{
${ }^{10}$ This is in spite of recent IMF reports suggesting that with unchanged borrowing patterns, the improvement in debt indicators is largely temporary, since the benefits from the debt relief fade as the relative importance of accumulated debt from new borrowing grows over time IMF (2006a).

${ }^{11}$ They may even anticipate the possibility of a further debt write-off in the future.
} 
$\mathbf{B} \mathbf{d}_{\mathbf{t}}=$ the target for domestic borrowing by the government (if negative, this would imply an increase in government deposits), and

$\mathbf{R}_{\mathbf{t}}=$ the target for tax and nontax revenue.

In part, the target for $\mathbf{B} \mathbf{d}_{\mathbf{t}}$ should reflect monetary policy considerations in terms of the appropriate goal for monetary expansion and the need to ensure adequate room for credit to the private sector (particularly if the growth strategy is heavily private-sector focused). It should also take account of the depth and capacity of the domestic capital market to absorb government borrowing without adverse effects on domestic interest rates. With the assumption of increasing aid flows, the medium-term time path of $\hat{\mathbf{E}}_{\mathbf{t}}$ would be expected to rise in the context of a government's MTFF, so that $\hat{\mathbf{E}}_{\mathbf{t}+\mathbf{2}}>\hat{\mathbf{E}}_{\mathbf{t + 1}}>\hat{\mathbf{E}}_{\mathbf{t}}$.

But it may not be appropriate to set the actual target for the time path of expenditures at its outer limit. Several factors should influence the height of the expenditure path that would be appropriate and sustainable to target.

- Debt-sustainability considerations may suggest limits on how much spending financed from borrowing can be accommodated (particularly if nonconcessional). In principle, the larger the share of grants that is expected, the less that solvency issues would be seen as a binding constraint. Here the quality of the spending program in terms of its potential growth effects is an important consideration in determining the acceptable level of borrowing. Debt sustainability scenarios should be used to judge how much borrowing is desirable, particularly if a country is below a reasonable debt threshold.

- $\quad$ Budget sustainability: There is the risk that in exploiting additional sources of fiscal space (particularly grants), expenditure commitments may be assumed that compromise the sustainability of the budget over the medium or even the longer term. The risks include the contingency that spending on grant-financed programs (e.g., for HIV/AIDS treatment or for O\&M on infrastructure) may need to continue even if the grants are not sustained; ${ }^{12}$ the normal volatility of aid disbursements; the potential distortions in expenditure patterns arising from donor priorities; ${ }^{13}$ and the potential for grants to weaken the incentive of authorities to expand the domestic revenue base, strengthen tax collection efforts, and address expenditure inefficiencies. The implied dynamics of the scaled-up expenditure program (whether financed from grants or

\footnotetext{
${ }^{12}$ In some African countries, e.g., Rwanda, a very high proportion of grants for HIV/AIDS treatment are channeled to the private sector. Government authorities worry that if such aid flows were to dry up, the government would have to step in and finance the continued provision of treatment.

${ }^{13}$ Again in the case of Rwanda, the authorities have argued that the flow of aid in the health sector could be used more effectively if it were not earmarked to specific vertical disease programs. Also see Chowdhury and McKinley (2006).
} 
loans) may also suggest limits. ${ }^{14}$ Some programs, once initiated, may prove even more costly in the future. ${ }^{15}$ Some of these issues can be explored by government in enhanced risk management assessments (see Section III.A). But the assessments may also suggest the need for limits, if not on the level of expenditure, then on its composition across spending programs.

- Growth considerations may also prove a constraining factor. Beyond a certain level, countries may find that aid-financed spending has diminishing returns. ${ }^{16}$ Countries may also worry that a sizeable increase in aid may lead to a significant real appreciation in the exchange rate that could prove damaging to export competitiveness. This is not an implausible scenario if higher aid flows are directed to social sector programs with low import content. This should not be viewed rigidly. If aid is used to enhance productivity in the economy and to remove key supply bottlenecks, such real exchange rate effects may not be encountered or their adverse competitiveness effects may be offset. Moreover, even if a front-loaded investment program gives rise to short-term losses in competitiveness, it may allow for enhanced rates of growth over the longer term, with a strengthening of the human capital base and increased availability of physical infrastructure.

But neither can the real exchange rate issue be dismissed as unimportant from the perspective of LIC policymakers, as was substantiated in a recent IMF (2005b) policy paper. If an LIC perceives the potential scaling up of its expenditure program as creating too much pressure on the real exchange rate, this might argue, ex ante, for a less rapid growth in the expenditure path. Equally, it might also argue for the accumulation of reserves if there were prospects that future absorption possibilities might improve.

\footnotetext{
${ }^{14}$ The focus on the MDGs suggests that much of the increased aid may be for programs that will be hard to discontinue, particularly if it leads to an increase in the size of the civil service.

${ }^{15}$ The increasing donor priority to vertical health sector spending programs is a vivid example. Unlike aid for most capital projects, for which the subsequent O\&M implications are fairly limited, higher spending, e.g., on AIDS treatment and care (viz., the provision of antiretrovirals and the treatment of opportunistic infections) requires at minimum continuity in future years. Indeed, once started, the cost of such programs for the affected individuals may increase (reflecting that some percentage of individuals may need to have recourse to higher cost second and third-line drugs, offsetting any possible cost reductions associated with mortality in the patient base).

${ }^{16}$ Flexibility may also arise in ways that are not intended by donors. Additional aid eases the budget constraint, allowing governments to engage in politically motivated spending and succumb to pressures for wage increases. Financing targets that emerge from needs-based MDG scenarios need to recognize that such leakages may be inevitable.
} 
- $\quad$ The expenditure mix: the heightened attention to the MDGs and the increased focus by donors on aid to the social sectors has provoked concern that there may be a bias against infrastructure and economic sectors. Yet the latter might not only have a more immediate growth impact, but also be supportive of an increasing tax base and less susceptible to expenditure rigidities (i.e., more rapidly completed and more easily adjusted downward if there are aid shortfalls). ${ }^{17}$ LIC governments could appropriately argue that if they are to expose their budgets to increased risk by applying aid to the social sectors, donors should at least be willing to provide greater assurance as to the sustainability of such funding.

- The absorptive capacity for expanded spending programs. Ex ante, the composition of the expenditure program either advocated within the PRSP or implicit in the priorities arising from donor assistance may suggest some limits on its size. This is particularly the case if there are bottlenecks in the production process, limits on available manpower, or weaknesses in the capacity to manage government programs or implement investments. Governments may, however, be able to change the composition of expenditures in ways that facilitate higher spending and absorption and limit the consequences of the uncertainties noted above. Ideally, sectoral spending agencies should be motivated to explore alternative options for effective, efficient, and more ambitious spending programs.

- The size of the public sector: Depending on the development model chosen, governments may be reluctant to allow aid to increase the role of the government in the economy beyond a certain level.

The key points of the above discussion are that the medium-term expenditure path (i) can constitute the fiscal anchor for the MTFF because it ensures a sustainable and solvent fiscal policy (as discussed above) ${ }^{18}$ and (ii) may need to fall below the outer limit that would be implied by the more optimistic approach to projecting potential aid

\footnotetext{
${ }^{17}$ In particular, some argue that if donors cannot make secure long-term commitments, the structure of public expenditure should favor investments that contribute to economic growth in taxable sectors but with relatively low recurrent cost implications. The most obvious areas are infrastructure investment, where there are high returns to both economic growth and poverty reduction, where the recurrent cost implications can be recovered from the user or may be relatively low (e.g, it is cheaper to maintain the road network once it has been rehabilitated to maintainable condition), and where the impact on the taxable economy should be relatively immediate. The neglect of economic growth in the first generation of PRSPs is increasingly recognized in the second, as reflected in the insertion of growth into the title of the PRSP in such countries as Ethiopia, Kenya, Ghana, Rwanda, Tanzania, and Vietnam. The required re-balancing of expenditure can be done either directly with donors, or by adjusting the use of domestic finance to take advantage of fungibility. Such rebalancing is facilitated when there is adequate integration of the development and recurrent budgets. Also, see World Bank (2006).

${ }^{18}$ Volatility in spending programs in the past has never been neutral across spending programs and has invariably been damaging to the productivity of projects and programs.
} 
inflows. Several important implications derive from the choice of the expenditure path as the anchor.

First, the choice of expenditure path may induce the government to accumulate financial reserves during the fiscal year. This would be the case if it believes that the risks associated with heavy reliance on external financing require some financial cushion to address potential volatilities.

Second, having chosen a given expenditure path as the anchor, ex post, this anchor may be consistent with a higher or lower level of domestic borrowing or domestic deposit buildup than had been expected ex ante. If there is a shortfall in aid flows, the government would need to draw on its financial reserves. Conversely, a higher level of external assistance may initially increase the reserve buildup beyond the original target. Each year of course, the government would need to revisit the MTFF, ${ }^{19}$ particularly if there has been a change in the overall aid environment - either positive or negative - that might influence the degree of optimism or pessimism for sustaining the proposed expenditure path.

Third, the choice of an appropriate fiscal policy cannot be made without consideration of the composition of a government's expenditure program. The composition will influence both the aggregate medium-term expenditure targets that would appear desirable as well as the appropriate level of budgetary reserves. Key issues to be considered are the import intensity of new spending programs, the O\&M implications, the extent of the shift toward spending programs which are difficult to reduce once started, and the costs to growth if the investment program is disrupted. The composition of the expenditure program will also have operational implications with regard to managing the associated risks. ${ }^{20}$ This is not to argue for or against any particular mix of government expenditures. LIC governments and agencies such as the World Bank are in the best position to judge the appropriate composition for realizing a government's policy objectives. Rather, it argues that fiscal authorities must take account of how the composition of expenditure may affect both monetary and fiscal management in the short term as well as the potential vulnerability and sustainability of the fiscal position over the longer term.

Fourth, recognition that the composition of the budget matters implies that ministries of finance must coordinate closely with decision makers in those sectors expecting a substantial increase in aid. In part, this relates to understanding the potential

\footnotetext{
${ }^{19}$ Countries with higher international reserves and scope for domestic borrowing will be more able to finance aid shortfalls and set expenditure closer to the outer limit. Conversely, countries lacking these conditions may be very constrained in their ability to finance shortfalls and may thus need to set a more cautious expenditure profile.

${ }^{20}$ For example, one might anticipate the need for higher reserves when the expansion in spending is for social expenditures with O\&M implications, as opposed to where the expansion is with regard to capital outlays with low O\&M effects.
} 
macroeconomic and fiscal sustainability consequences of the way in which spending in such sectors takes place. It also argues for exploring whether adaptations in the pattern of expenditure can lessen any potential conflicts with macroeconomic policy imperatives. Further, it is important to achieve greater clarity as to the risks involved in a sector's expansion and an understanding of how these risks, e.g., a future shortfall in funding, would be handled. A difficult remaining question is how much of the burden of adjustment of sectoral risks would need to be borne at the sectoral level as opposed to adjustments in other areas of the budget or in the aggregate fiscal stance.

Fifth, the approach suggested above recognizes that both macroeconomic stability and expenditure smoothing need to be identified as policy objectives. Due to the precarious nature and weak institutions of many LICs, the maintenance of macroeconomic stability has often taken precedence over expenditure smoothing. However, as many more LICs become "mature stabilizers," as fiscal institutions improve, and the focus on sustained poverty reduction increases, the quality of expenditure programs over the medium to long term becomes critically important. Particularly for social expenditure programs, but also for the recurrent costs of some programs in the economics sphere (agricultural extension, road maintenance, research and development), there are significant costs to volatility in budgets. ${ }^{21}$

Finally, LICs should, as far as possible, base their fiscal programming, in the context of IMFsupported programs, on an MTFF (assuming it is realistic). A disconnect between yearly fiscal programs (whether or not they are carried out under IMF-supported programs) and the MTFF should be avoided. Both exercises should be guided by the same recognition of the desirability of a smooth, well-sequenced expenditure path, particularly in the social sectors. As the progress of LICs towards the MDGs continues to be hampered by fragmentation of all sorts - competing medium-term scenarios, parallel budgets, extrabudgetary spending, a dichotomy between budget planning and execution, and a lack of alignment between current and investment spending - the focus of fiscal programming and management should be on integration and alignment by the authorities.

\section{Fiscal, Monetary, and Exchange Rate Policy Coordination}

In many ways, the decision by the government on the size and composition of the MTFF will have important implications, in a broader sense, for the government's macroeconomic policy framework. The decision on how much to both absorb and spend of aid will strongly influence the macroeconomic policy environment and, in particular, the pressures on the nominal exchange rate or the domestic price level. Given the inevitable uncertainties and unanticipated developments that may arise, it is particularly important for the ministry of

\footnotetext{
${ }^{21}$ The objective is less smoothness in the aggregate expenditure path and more in the budgets of those expenditure programs for which there may be a high cost to volatility. Thus, if there are expenditure programs (e.g., some, though by no means all capital expenditure projects) for which some delays in implementation can be handled without significant disruption, some variability can be accepted. The problem often arises however that considerations of economic loss are not the principal criteria for how budgetary cutbacks are allocated.
} 
finance and the central bank to closely coordinate fiscal, monetary, and exchange rate policies, not only in the specification of the underlying macroeconomic policy framework but also in day-to-day policy management.

In a situation where the government budget is heavily dependent on aid flows, the impact of aid on the macroeconomic environment is particularly critical. Aid can only be absorbed by allowing the external non-aid current account deficit to widen, either through direct imports by the government or through conducive exchange rate and monetary policies. Aid inflows can be an important source of liquidity pressure. The amount of such pressure will depend on how the aid is used. When used to finance government imports, it would have little direct impact on liquidity. However, when used for spending on domestic goods and services (e.g., local wages and salaries), it will add domestic liquidity pressures that can potentially be inflationary. ${ }^{22}$

The macroeconomic impact of aid thus depends on the fiscal, monetary, and exchange rate policy response (see IMF, 2005b). As noted earlier, for the finance ministry, one critical question is how much to spend out of the additional aid. As one of the key actors in determining the overall growth strategy, the finance ministry will also be concerned with the impact of aid on the real exchange rate and on the competitiveness of the economy. For the central bank, the concern is how to manage the liquidity impact of increased aid-induced spending in a way that is consistent with a low inflation environment and sustainable real growth. It must thus worry about whether the use of aid can be absorbed and the nature of the pressures it will engender on the nominal exchange rate and on the level of domestic prices. If the central bank is focused on keeping inflation at bay while still managing the nominal exchange rate, one could observe the central bank seeking to limit the extent of absorption of additional aid that the government may actively be seeking to achieve through higher spending. $^{23}$

Thus, pivotal for managing a scaling up of aid flows is consistent coordination and reconciliation of the objectives of fiscal policy with the exchange rate and monetary policies pursued by the central bank. Several key factors will determine the pressures that fiscal policy may create for monetary policy in managing the absorption of aid inflows:

- the government's decision on how much to spend of the aid inflows and the composition of that spending;

\footnotetext{
${ }^{22}$ This contrasts with domestic spending financed from tax and other revenue sources, where the liquidity impact of such spending is offset by the contraction in base money arising from private agents drawing down their currency holdings or bank deposits in order to pay taxes.

${ }^{23}$ This is obviously a strategy that cannot work. A central bank has just one instrument and cannot control two variables (inflation and the nominal exchange rate). Trying to both limit inflation and the nominal appreciation of the exchange rate-i.e., trying to target a real variable (typically, the real exchange rate) - can create obvious tensions in macroeconomic policy management.
} 
- $\quad$ how much aid is not spent but rather used to build up reserves; ${ }^{24}$

- $\quad$ the government's approach to financing expenditure programs in the event of volatility in aid flows, viz., the extent of reliance on drawing on accumulated deposits at the central bank. This implies that the fiscal deficit inclusive of grants may vary in reaction to volatility in aid flows; and

- $\quad h o w$ additional aid resources are used. ${ }^{25}$ In addition to imports, inflationary pressures can be lessened if aid is used to remove bottlenecks to increased productivity, particularly in the nontraded goods sector.

If a central bank is faced with a substantial increase in liquidity pressures arising from the use of aid, there are two basic ways the liquidity impact can be sterilized:

- It can sell government securities. Since such a policy is normally achieved by raising interest rates, private sector borrowing and spending is discouraged, with the public sector gaining resources at the private sector's expense. But an increase in the outstanding stock of domestic public debt and potentially higher domestic interest rates may increase the government's debt servicing burden in future years. This is problematic if the additional domestic borrowing is not for productive purposes (e.g., election-related spending).

- It can sell foreign currency in the interbank market, with the possible consequence of a more appreciated exchange rate. Sales of foreign exchange allow donor inflows to expand national spending, as the increased spending in foreign markets is reflected in a larger external current account deficit (i.e., the counterpart to the real resource transfer from the donor countries). ${ }^{26}$

The appropriate balance between domestic debt and foreign currency sales will vary with market conditions and needs. In practice, central banks have been reluctant to reduce foreign exchange reserves and/or allow the nominal exchange rate to appreciate, preferring the burden of adjustment to fall on either a reduction in fiscal spending or on the private sector through higher interest rates (i.e., limiting the effective absorption of aid flows). ${ }^{27}$

\footnotetext{
${ }^{24}$ A decision by government to not spend all of its aid receipts might also be used to pay back some domestic debt, though this would have the consequence of expanding liquidity in the economy.

${ }^{25}$ Note the strong impressionistic relationship between the increase in aid and the imports of expensive $4 \times 4$ vehicles in many low-income countries.

${ }^{26}$ The authorities can also resort to "direct instruments" such as increasing reserve requirements or, as a onetime measure, transferring public sector deposits from commercial banks to the central bank but these measures may be distortionary and cannot be used on a continuous basis.

${ }^{27}$ Given the volatility and unpredictable nature of aid, a central bank's natural conservatism is understandable. Celasun and Walliser (2006) cite a number of countries in which 80-90 percent of annual budget support was disbursed in the last quarter of the year, which means that either domestic financing temporarily fills the gap
}

(continued) 


\section{Short of approaches to increase aid-financed imports or enhance productivity, LICs must accept that absorption of significant scaled-up aid is likely to require an appreciation of the real exchange rate. The alternative is to engender inflationary pressures which would essentially effect a real appreciation in any case.}

The challenge of monetary and fiscal policy coordination in the context of scaled-up aid is particularly difficult when LICs are in a regional currency union (e.g., as in West Africa). Here individual member countries cannot pursue an independent monetary policy. The regional central bank is charged with the responsibility for sterilizing or dampening the inflationary pressures that may arise in the union, particularly when there is a nominal exchange rate peg. Countries in such cases face the following dilemma (as illustrated for the case of the West African Economic and Monetary Union (WAEMU)). Fiscal rules are used to limit the extent to which governments can, through fiscal policy, create monetary pressures by running deficits. Effectively, these rules restrict the ability of a government to spend additional aid flows (see Box 1). Yet the promise of additional aid would create considerable pressure for an individual country to ignore these rules, allowing the aidfinanced spending to take place. But such spending, particularly if focused on nontradables, may create inflationary pressures that would be hard to square with the maintenance of a nominal exchange rate peg.

The issue is further complicated by the fact that member countries may differ in their ability to obtain donor assistance. Efforts by the regional central bank to sterilize additional liquidity emanating from one country will impose sterilization costs that impose negative externalities on nonrecipient countries. Thus, as with any other country dedicated to maintaining a hard exchange rate peg, the approach advocated above in terms of receptiveness to the use of aid resources may conflict with the objective of price stability. The problem in the regional currency union case is that the individual country does not have the option to change the peg and allow a nominal appreciation in the event that aid flows are substantial.

Two alternative approaches may be considered. One is for the regional central bank to allow the price of nontraded goods (notably wages) to rise if different countries get greatly differing amounts of aid. The implied real appreciation of the exchange rate in the high aidreceiving countries would facilitate a higher current account deficit in these countries, which could be financed from the higher reserves derived from aid. Alternatively, the aid-receiving countries could seek to influence the composition of spending, both as between tradables and nontradables and in terms of investments that can be shown to substantially increase productivity and remove bottlenecks in the economy.

(and is accommodated by the central bank) or expenditures must adjust. In such cases the central bank may need reassurance that the financing will be forthcoming before endorsing the expenditure that may lead to a "temporary" drawdown of foreign reserves. 


\section{Box 1. Reconciling Fiscal Rules in a Currency Union with Scaled-Up Aid: The WAEMU Case}

Scaled-up aid resources may have important implications for the design of fiscal rules for countries participating in a regional currency union that are the expected recipients of such inflows. In particular, fiscal rules that are geared towards fiscal consolidation through the control of fiscal balances might counteract projected expenditure acceleration financed by aid resources and debt relief. ${ }^{28}$ Existing fiscal rules, including convergence criteria on fiscal balances in currency union member states, might thus need to be adapted to reflect this new aid environment.

The WAEMU Regional Pact of Convergence, Stability, Growth, and Solidarity, which was adopted in 1999, strives to promote the convergence of WAEMU member countries' economies, and specifies a set of first- and second-order convergence criteria to which countries should comply. The key criterion among the four first-order criteria is that the basic fiscal balance must be in balance or surplus. The second-order criteria comprise, inter alia, criteria on capping the ratio of the wage bill to tax revenue to 35 percent, and ensuring the ratio of domestically financed public investment to tax revenue exceeds 20 percent. $^{29}$

These criteria, in particular the one on the basic fiscal balance, might no longer be appropriate in a scaled-up aid environment. The fiscal balance is calculated as revenue, excluding grants, minus expenditure excluding foreign-financed investment. As the WAEMU (2006) commission has also noted, this poses the problem that aid- and debt-relief-financed expenditure would be reflected on the expenditure side, but the corresponding resources would remain excluded from revenues, thus worsening the basic fiscal balance. Controlling the wage bill in relation to tax revenue might also prove difficult if aid-financed spending is channeled to the hiring of more personnel in the social sectors. Finally, if a large part of public investment is financed externally, bringing the ratio of domestically financed investment to tax revenue to over 20 percent may also prove difficult.

Recognizing these shortcomings, WAEMU proposed adding supplementary fiscal criteria to adjust for expenditure financed by increased aid inflows and debt relief. One suggested approach is to include all aid and HIPC debt relief on the revenue side when calculating the basic balance. Alternatively, the balance could be calculated by taking only tax and other revenue into account, and subtracting current expenditure in order to have an indicator of government saving.

\footnotetext{
${ }^{28}$ One additional positive ramification of these rules is that they may help promote public financial management reforms across member countries, e.g., harmonization of budgetary classifications and procedures.

${ }^{29}$ Compliance with these criteria proved difficult. According to the pact, all member countries were supposed to be in full compliance with all criteria by end-2005, but none was. Preliminary data show that seven out of eight member countries violated the basic balance criterion.
} 


\section{Enhancing the Management OF Fiscal RiSK}

Aid volatility and the lack of short-term and long-term predictability in aid commitments add to the inherent uncertainties facing developing countries. ${ }^{30}$ Volatility leads to instability, uncertainty, and risk. At the macroeconomic level, it has a direct negative impact on longterm growth (Fatas and Mihov, 2006; Celasun and Walliser, 2006). With a scaling up of aid, the absolute magnitude of the volatile element of aid flows may also be larger. For example, if in the past, the standard deviation of aid flows was, hypothetically, 15 percent, an increase in the share of aid flows from 10 percent of GDP to 20 percent, would imply that the potential standard deviation could rise to 3 percent of GDP.

Short-term unpredictability - in terms of the magnitude or timing of aid disbursements within the budget year-can complicate macroeconomic management through a variety of channels. Large injections of liquidity into a thinly monetized economy may make systemic liquidity management more difficult and/or negatively impact the terms of trade. At a more microeconomic level, the need to impose ad hoc limitations on expenditure can be extremely disruptive, tending to favor noncompressible current expenditures (usually the wage bill), the donor-financed capital budget, and politically powerful ministries. Moreover, with domestic sterilization of the government's exposure to volatility often shifted to the private sector, there can be adverse effects on investment.

Long-term unpredictability engenders a different kind of risk. Expansion of recurrent spending programs creates expectations as well as contractual and moral commitments. If the amount of additional aid to finance social expenditure programs is expected to be substantial, governments will need to design an appropriate strategy for scaling up, including the appropriate sequencing of training and hiring. If there is uncertainty as to whether the higher aid flows will eventuate or be durable, ministries of finance may rightfully be cautious as to how much to invest in training programs or how many to hire on a permanent basis. In the narrow case of expanding HIV/AIDS treatment programs, the risk of having to discontinue treatment not only would have adverse effects for the population concerned, but would also pose larger risks (in terms of the likelihood of the spread of resistant strains of the virus).

Macroeconomic stability and expenditure smoothing both need to be identified as policy objectives. Due to the precarious nature and weak institutions of many LICs, the maintenance of macroeconomic stability has often taken precedence over expenditure smoothing. However, as many more LICs become mature stabilizers, as fiscal institutions improve, and as the focus on sustained poverty reduction increases, the quality of expenditure programs over the medium- to long-term becomes critically important. This has increasingly been recognized in programs with the IMF, where adjustments are often made to protect poverty spending in the face of external shocks and aid volatility (see below).

\footnotetext{
${ }^{30}$ See Bulir and Hamann (2006)
} 
Fiscal risks can be managed through a combination of enhanced risk assessment, selfprotection, self-insurance, and risk pooling. Enhanced risk assessment relates to the way fiscal risks are considered, managed, and acted upon in the implementation of both aggregate fiscal policy and sectoral program design. Self-protection mechanisms seek either to prevent the volatility from occurring or limit the extent of exposure to significant volatility or unpredictability. In a longer-term context, increasing the share in GDP of government revenues is also an approach to self-protection. Self-insurance and risk pooling seek to transfer income built up during good times to deal with the potential for negative shocks in the future, while recognizing that permanent changes in income or aid flows would eventually need to be reflected in an adjustment of expenditure. The technical and political challenge is to distinguish between such shocks.

\section{A. Assessing Short-Term Financing Risks}

Debt sustainability assessments are seen by the World Bank and IMF as an important vehicle for judging potential solvency risks associated with external borrowing, both by emerging market countries and by LICs. Particularly for countries with a history of particularly volatile aid flows or recurrent liquidity problems, the IMF-World Bank Debt Sustainability Framework (DSF) template can clarify some of the key fiscal policy options and risks and refine the choice of an appropriate anchor for fiscal policy (particularly in the post-MDRI environment where debt ratios for many countries have been significantly reduced).

One option offered by the template is to simulate the operation of alternative fiscal rules. This exercise could include the use of:

- $\quad$ scenario analyses to assess the risk of debt distress associated with alternative assumptions (ambitious, realistic, and pessimistic) over the typical time frame of 20 years. Scenarios would need to be plausibly related to alternative borrowing plans, interest rate levels (embodying concessionality), and potential growth paths. The latter would be related to the broad composition of expenditure (as between infrastructure investments and current expenditure) and the level of private investment. Scenarios could also assess the potential consequences of a significant increase in grant-financed expenditure programs, taking account of their recurrent expenditure implications or of the scaling up of sectoral programs that are hard to reverse;

- $\quad$ stress-tests to explore country-specific sources of uncertainty. By attaching some judgmental probability estimates on the likelihood of different assumptions (e.g., shocks on aid flows), a perspective is possible on the risks associated with alternative borrowing strategies. The gains from smoothing strategies built into the fiscal targets, including the build-up of assets during positive shocks, could easily be assessed by comparing outcomes under alternative fiscal rules; and 
- $\quad$ assessments that focus on the more immediate medium-term time frame-say, five years - to explore the prospects for maintaining a targeted expenditure profile, taking account of potential shocks to the fiscal accounts and liquidity constraints. Such assessments would provide a useful complement to the DSF's focus on long-term solvency, particularly in cases where debt relief has been significant and/or considerable grant assistance is being provided. In such cases, government may face a challenge in managing cash flows to ensure that expenditure plans are implemented smoothly (i.e., facing a liquidity constraint) and alleviating absorptive constraints. Where access to financial markets (international and domestic) is typically limited, even a temporary shortfall in aid is likely to disrupt budget execution, particularly for investment spending where cuts in outlays may be permanently lost. ${ }^{31}$ Annex I illustrates the possibilities afforded by such an exercise for the case of Ethiopia. The stress tests show that the consequence of volatility in the growth of grants can be different as between the vulnerability to solvency (in a post-MDRI context) and the vulnerability to liquidity risk. An extreme aid shock would be difficult for authorities to offset through domestic financing.

Finally, country-specific indicators of short- and medium-term aid vulnerability might usefully be considered. Given the more immediate nature of liquidity concerns, such risk indicators are best formulated in the context of medium-term fiscal projections, taking account of potential intra- and inter-year volatility and unpredictability (see Table 1 for a sample of indicators). A rolling medium-term fiscal program could be based on the anticipated availability of external resources flows (adjusting for the historic variance between commitments and disbursements), and adjusted to incorporate absorptive capacity developments and the authorities' appetite for risk, as quantified by the indicators. This framework would provide a country-specific, rules-based framework that suggests, but does not prescribe, a gradual increase in expenditure based on a scaling up of aid. ${ }^{32}$

\footnotetext{
${ }^{31}$ See Celasun and Walliser, 2006.

${ }^{32}$ A gradual scaling up of expenditures would be consistent with the development of a risk-management framework that included measures to mitigate some of the risks identified. It would also be consistent with the assumption of decreasing returns to new aid investments (see Clemens and Radelet, 2003), although infrastructure investments in particular may be lumpy.
} 
Table 1. Sample Liquidity Indicators for Scaled-Up Aid

Indicator

The ratio of the primary fiscal
deficit (excluding grants) to GDP

The ratio of domestic (nongrant) revenue to current expenditures

The ratio of government deposits to reserves/short-term debt

The ratio of short-term debt to either GDP or to total debt

\section{Comments}

A useful indicator for measuring the direction of fiscal policy and the exposure of the fiscal balance to aid shocks. Contrasting the magnitude of the deficit against the historical volatility of anticipated aid-flows can provide a measure of the expected loss from an aid shock that would then need to be financed through a combination of fiscal consolidation, debt accumulation (domestic or foreign), and a drawdown of reserves. ${ }^{33}$ The focus on the non-grant fiscal balance also supports the objective of eventually reducing the reliance on aid flows.

Indicates the extent to which domestic resources cover the least compressible forms of expenditure, although cutting capital spending could reduce long-term growth (and may breach some contractual obligations). This indicator provides a crude measure of a country's ability to maintain its basic operations in the face of a rapid decline in external resources. Some natural resource producers have introduced fiscal rules that require current expenditure to be covered by tax and other revenue while resource revenue finances investments (e.g., Botswana).

An indicator of reserve adequacy in countries with significant but variable access to capital markets. This indicator could also be subdivided to consider domestic and foreign debt dynamics.

An indicator of the rollover and interest rate risk. In many LICs with thin financial markets, there is limited scope for drawing on bank finance without undermining macroeconomic stability. Uneven or unpredictable recourse to domestic financing may sharply increase debt service costs.

\section{B. Self-Protection and Fiscal Credibility}

Policies of self-protection seek to reduce the volatility and unpredictability of aid flows. One obvious approach is for a country to be conservative concerning how much additional aid to accept, reflecting that volatility may arise from factors exogenous to a recipient country's own behavior (e.g., other fiscal or balance of payments pressures on donors; other demands for aid that are seen as politically more acute, etc.). ${ }^{34}$

${ }^{33}$ The risk of a prolonged under-performance in scaled-up aid strengthens the case for developing such a MTFF, including an approach to risk management and for building a prudential reserve cushion and contingency measures that could be activated in specific circumstances.

${ }^{34}$ A country may also recognize that its own actions, though appropriate in terms of its own political or economic considerations, may give rise to adverse donor reactions. 


\begin{abstract}
A track record of transparent and prudent fiscal policies may be the best form of selfprotection. In response to periods of severe disequilibria, many LICs have resorted to institutional mechanisms such as rule-based cash budgets which have proven successful in reducing inflation and achieving a track record of fiscal discipline. However, these mechanisms have a cost. Strict adherence to cash-budgeting places the burden of adjustment for revenue shortfalls, including aid, on expenditure programs. Where money-demand is growing strongly, it can also be unnecessarily deflationary. ${ }^{35}$ The difficult choice for many LICs and donors is how to manage the transition to more flexible fiscal management while still retaining the benefits of enhanced fiscal discipline.
\end{abstract}

The value of fostering a shared strategy with donors: A well-articulated MTFF for which there is a strong political and policy commitment by the government can improve the link between the "need for" and the "availability of" resources. This framework should be used to set out common objectives which can be agreed with donors, identify the main fiscal risks, develop possible mitigating strategies, and allow targeting of external assistance to areas where implementation capacity is sufficient to absorb more aid productively.

Greater flexibility can also be sought in the design and implementation of aid-financed expenditure initiatives. The scope for flexibility has been weakened as donors have moved from investment projects (which can be delayed or downsized) towards less compressible entitlement and recurrent cost-intensive spending programs. One obvious approach is to rely more on the use of contractual staff in expanding the social sector. Contracts of medium-term duration (three-five years) give flexibility in the event of aid discontinuity. Such contracts can be specified to include most of the benefits normally associated with civil service employment. Such an approach effectively adopts the type of contractual arrangement already common for some capital expenditures. ${ }^{36}$

How aid is used can also be a form of self-protection. Easing supply bottlenecks can mitigate the adverse effects of aid volatility while improving domestic absorptive capacity. A substantial boost to aid-financed investment in infrastructure can contribute to the increased sustainability of long-term development efforts. Careful investments to bring down production costs and improve productivity may offset the impact of a nominal exchange rate appreciation on competitiveness. As noted, increasing the noncompetitive import content of aid can further reduce pressures for a real exchange rate appreciation. ${ }^{37}$ To incorporate such considerations in the formulation of fiscal policies, macroeconomists need to be informed on

\footnotetext{
${ }^{35}$ Adam and Bevan, 2001; and IMF, 2005b.

${ }^{36}$ The political feasibility of such an approach may prove difficult if it were necessary to release such teachers or health workers.

${ }^{37}$ However, if the increase in imports simply substitutes for goods that would otherwise be produced locally, it would still cause a rise in the relative price of nontradables, and thus put pressure on the real exchange rate.
} 
sectoral investment priorities (water, electricity, telecommunications, and transportation infrastructure as well as human capital) and on the role that different outlays can play in removing key supply bottlenecks.

The development of a more liquid financial market can enable less destabilizing access to domestic financing. Government cash flows generally have a significant impact on the liquidity of the banking sector. If fiscal management is stable and credible, it can catalyze the development of deep and liquid money and bond markets. This can not only bring down the cost of funds to all borrowers, but also help to buffer the effects of domestic and international shocks to an economy by providing borrowers with readily accessible domestic financing. It can also reduce a government's exposure to interest rate, currency, and other financial risks.

More controversially, the approach of ring-fencing priority expenditures - observed in several African countries — can be seen as a form of self-protection with respect to

priority expenditure areas. The goal is to ensure that specified programs-e.g., for poverty reduction or HIV/AIDS treatment, etc.- - are protected against budgetary cuts in the event of revenue volatility, with the impact effectively borne by non-priority sectors. In Uganda (see Box 2), the Poverty Action Fund is a virtual fund used to channel identified resources into priority poverty-reducing programs. The approach was seen to facilitate additionality in spending as well as provide greater transparency and accountability. It also allowed the government to signal to donors its highest priorities. However, there are downside aspects to ring fencing. It can create perverse incentives for donors, deterring them from more general budget support since it may imply spending on nonpriority areas. It can be subject to abuse, as budget reclassification can lead to inclusion of low-priority items within the "ring." Finally, it intentionally creates rigidities in budgetary practices. A form of earmarking, multiple ring-fenced budgetary categories can easily develop and concentrate any volatility within the non-protected portion of the budget.

Finally, a more durable form of self-protection can be achieved by enhancing the mobilization of tax and nontax revenues. The availability - if not the mere prospect - of increased aid may weaken a government's incentive to mobilize tax and other revenue (e.g., see Gupta and others, 2003). Politicians may be unwilling to enforce tax compliance when "free" funds are available. Particularly for LICs with a revenue share significantly below the average for peer countries, the fiscal policy response to a scaling up of aid should include a targeting of the domestic revenue mobilization effort so as to raise the revenue ratio to the $15-20$ percent of GDP range. 
Box 2. Ring Fencing of Priority Expenditures: Uganda's Poverty Action Fund (PAF)

Uganda's PAF is a virtual fund created in 1998 to channel identified resources into priority poverty-reducing programs (e.g., primary education; primary health care, including control of HIV/AIDS; agricultural extension; feeder roads; water and sanitation; and law and order). Its objective was to establish a transparent mechanism to ensure that specific resources from debt relief "earmarked" donor funds and government revenues were allocated to key programs within the Poverty Eradication Action Plan (PEAP), originally formulated in 1997. These allocations were thus protected from budget cuts, i.e., if budgetary resources fall short of targets, PAF spending is "ring fenced" and executed on a priority basis. The PAF is virtual because it only amounts to a set of budgetary codes for identified programs, without any corresponding institutional mechanism. The PAF has three essential elements to achieve its objective.

First, it only includes public expenditures considered of the highest priority from a poverty-eradication perspective. The criteria used for accessing the PAFs are based on whether the planned activities/programs are mentioned in the PEAP; directly reduce poverty; offer services to the poor; have high economic and/or social returns and are well developed; and have a budget for a specific financial year.

Second, the PAF mechanism allows for a more transparent understanding of the additionality of donor resources, comparing current financing with the financing level of the same activities in the 1997/98 budget. When created, donors wished to ensure that the resources they committed to particular sectors led to increases in the total resources devoted to these sectors. Hence the presentation of spending plans in the PAF clearly showed that government and donor funds committed to the Fund are additional to the government's resources.

Third, special measures were taken to strengthen the transparency and accountability of the high-priority expenditures managed under the PAF. Funds are released either as conditional grants to the districts or through the development budget. Five percent of its resources are set aside for enhancing existing monitoring, accounting, and auditing procedures. Data and reports on the use of the PAFs resources are published regularly and discussed at quarterly meetings, chaired by the government, and at which donor agencies and NGOs attend. The media participate in order to enhance accountability through sharing information with the public.

The PAF has proved a transparent and successful mechanism. Donors have relied increasingly on it in providing aid, and spending through the PAF increased from about 6 percent of total spending in FY 2000/01 to 24 percent in FY 2005/06.

The reasons are several. First, an adequate revenue base is essential for both short-term implementation and long-term planning of spending programs. In the short term, a large revenue base can insulate a budget against interruptions in donor support. Over the long term, a buoyant domestic revenue stream allows a country to gradually replace external financing, thereby maintaining spending levels commensurate with policy priorities as aid is phased out. Second, strengthening the revenue effort allows for a further increase in fiscal space for priority spending. Third, increasing the revenue efforts fosters accountability. More transparency in the sources and uses of government revenue can contribute to a strengthening of institutions and enhanced governance. In particular, citizens should be informed about the availability of prospective resources for spending, including tax expenditures (i.e., revenue losses due to exemptions and tax incentives). As these are typically granted to vested 
interests, awareness of their existence and magnitude can generate pressures from excluded groups to undertake reforms to broaden the tax base.

\section{Self-Insurance}

By building fiscal reserves, governments can cushion ongoing expenditure programs, at least over the short to medium term, against the volatility of aid flows. ${ }^{38}$ In the same way that central banks hold foreign exchange reserves to manage volatility in the balance of payments, the fiscal agent can accumulate deposits to help smooth expenditures and offset aid shortfalls. These higher fiscal deposits would be matched by higher foreign exchange reserves held by the central bank, since large movements in domestic financing could be destabilizing for LICs lacking deep financial markets. In the event of a temporary shortfall in foreign aid or another shock, as the government draws down its deposits, some of the accumulated foreign exchange deposits can be sold in the domestic market in order to smooth expenditure.

Some LICs have pursued such a policy on a de facto basis by saving incremental aid (although this could also be more a consequence of additional aid confronting absorptive capacity constraints rather than as a policy choice). ${ }^{39}$ However, just as many oil producers have argued that it is difficult to save oil windfalls in the face of pressing social and infrastructure needs, many LICs may find it difficult to abstain from an expansion in expenditure programs. ${ }^{40}$ Donor buy-in to an increase in reserves would also be important, since this would effectively mean the saving of some portion of donor assistance as a cushion against volatility.

How large should reserves be? Studies suggest that the volatility of aid can be very large, exceeding that of fiscal revenue, with coefficients of variation usually in the range of 40-60 percent of the mean aid flow (Bulir and Hamann, 2003, 2006). This can impose high costs on vulnerable, aid-dependent economies. It can also increase the danger of slipping into a lowlevel equilibrium trap whereby countries, budgeting prudently within a sound MTFF, may logically discount pledges of assistance, while donors, seeing lower funding gaps, reduce their aid pledges and commitments.

\footnotetext{
${ }^{38}$ Over the longer term, and given the large opportunity cost of reserve accumulation, such a policy cannot guarantee the sustainability of an expanded spending program if, in the worst-case scenario there were to be a sharp drop in aid flows.

${ }^{39}$ Ghana and Ethiopia were cited as witnessing periods when incremental aid was saved, although some of this may have had to do with weaknesses in the budgetary process (see IMF (2005b). In the case of Ethiopia, it reflected that its international reserves had been significantly run down following the conflict with Eritrea. Moreover, it was rapidly reducing its high defense outlays and unsustainable domestic budget financing, while raising pro-poor spending.

${ }^{40}$ For a discussion of oil producers see, Katz and others, 2004.
} 
The target level for such reserves and the specification of the conditions under which they may be accessed must inevitably be country specific. Calibration may initially be based on the historic level of volatility of aid and other shocks. But if there is a prospect of greater aid, the reserve target would need to also consider the potential risks from a disruption to the financing of government programs at a scaled-up level. Recognizing that the traditional measure of months of imports may not be satisfactory in the context of an aid-dependent economy, Eifert and Gelb (2005) have proposed that an equilibrium buffer stock should include a reserve tranche of 50-100 percent of annual aid-financed spending (equivalent to two-four months of import cover in a typical aid-dependent LIC with an annual import-toGDP ratio of 40 percent). They contend that this would be effective in smoothing expenditure in most periods within the range of historic levels of aid instability (based on Bulir and Hamann, 2003). They also note that most LICs have foreign exchange reserves equivalent to about five months of imports, which they deem adequate for the observed aid flows and volatility.

Eifert and Gelb recognize that their proposed mechanism would work best when fluctuations are serially independent or tend to offset each other in subsequent years. The buffer stock would be most vulnerable when disbursement shocks are autocorrelated, since countries would experience a series of negative shocks. In the case of large negative shocks to aid flows, such a reserve buffer would be depleted in several years, during which time countries and donors would have to organize an emergency response.

The question that arises is whether their proposal should be modified if aid is substantially scaled up - say, doubled from 10 percent of GDP to 20 percent or even more? If the above relationships hold and the degree of volatility remains unchanged, the reserve buffer would have to increase to at least six months of import cover. Clearly, if the degree of aid volatility also rises with a scaling up of aid, a larger reserve buffer would be needed. ${ }^{41}$ A fortiori, with a change in the composition of aid towards programs which are less easily adjusted, an even higher level of reserves might be advisable. In moving forward, it might also be worth assessing the level of net international reserves against a broader measure of need that reflects the use of reserves to smooth externally financed expenditures.

\footnotetext{
${ }^{41}$ One must also recognize that political economy incentives may lead a country-perhaps even rationallyagainst pursuing this type of approach of a smooth expenditure stream, buttressed by a reserve management policy. In a context where "absorb and spend" is the leitmotif, and where information on true absorptive capacities and policy preferences is asymmetric, countries may be tempted to signal to donors their ability to absorb additional aid by spending windfalls, while covering shortfalls with domestic borrowing. Domestic debt would then ratchet up as aid fluctuates, ultimately threatening the credibility of the fiscal anchor. The likelihood of such strategies being used for signaling purposes - and the corresponding need for well-designed fiscal targets - increases with the perceived risk that donors may reduce aid if it is not spent, and that grants would automatically increase if debt grows out of control. It also decreases with the country's true absorptive capacity. Some indeed have argued that such an approach would be rational with respect to accumulating additional debt. Past experience suggests the possibility of debt forgiveness again being provided.
} 


\section{Risk Pooling}

Donors could also devise more flexible compensatory financing mechanisms to limit the impact of aid shortfalls. Several new initiatives along these lines have been developed, including formalized partnership agreements, the Paris Declaration on Aid Effectiveness and the IMF's Exogenous Shocks Facility. However these mechanisms remain administratively cumbersome (given long data lags in LICs) or ad hoc in character. Consequently, they fail to provide the required support on a timely or consistent enough basis for countries with thin financial markets to avoid the costs of fiscal adjustment.

An alternative approach to cushion volatility would be to link debt repayments or aid disbursements to key macroeconomic variables. There is a growing academic literature on the benefits of tying debt instruments to particular macroeconomic events, such as the level of GDP or a shock to a key cash crop. ${ }^{42}$ Such a link can provide a measure of "automatic stabilization" against shocks, both by reducing debt payments and bolstering credibility by narrowing the swing in debt-to-GDP ratios. While a paucity of reliable information has inhibited the development of state-contingent debt instruments, there are fewer barriers to donors providing some explicit state-contingent financing in the context of formalized partnership agreements or pooled financing arrangements and MTFFs (in effect, formalizing the already established practice whereby donors compensate LICs in the face of natural disasters, droughts, etc.).

IMF programs can also provide short-run discretion in circumstances when macroeconomic outcomes deviate from central projections, including when aid flows are higher or lower than expected. Historically, IMF-supported programs have often adjusted for both positive and negative aid shocks. While PRGF-supported programs usually do not have explicit targets for expenditure smoothing, adjusters have increasingly been used to compensate for aid volatility. ${ }^{43}$ These have enabled countries to maintain or even increase spending in the face of significant shocks (e.g., aid inflows increased sharply to Mozambique in response to the floods in early 2000 and to Ethiopia in response to the 2002 drought). Conversely, by allowing some increase in net domestic financing of the government and by lowering international reserve targets, negative aid surprises have only required a limited degree of fiscal adjustment. For example, the IMF-supported program in Tanzania allowed increases in the net domestic financing target by 100 percent of any aid shortfall. To the extent that an IMF-supported program provides state-contingent resources, such funds provide a form of insurance, while the agreement on a medium-term fiscal program provides a transparent, external endorsement of a countries medium-term strategy (a form of selfprotection).

\footnotetext{
${ }^{42}$ For a review of state contingent debt instruments see, IMF (2003).

${ }^{43}$ IMF (2005b), Box 3.
} 


\section{Institutional Approaches to FaCiLitate Fiscal Management with SCALED- UP AID FLOWS}

The previous sections have highlighted alternative approaches to strengthen fiscal policy management in the context of a scaling up of aid. But the adoption of strengthened policies is not independent of a country's capacity for implementation. The latter will shape whether donor policies facilitate or hamper a country's efforts to absorb additional aid effectively. Strengthened public financial management (PFM) is well-recognized as fundamental. But five other areas require attention: (i) action by donors to make their aid policies more effective; (ii) efforts by aid recipients to facilitate donor coordination and strengthen aid management; (iii) the embedding of a medium-term perspective into fiscal policy; (iv) the strengthening of institutions and the processes for the coordination of fiscal and monetary policy; and (v) the development of a capacity for independent audits of the fiscal policy framework.

\section{A. Strengthening Donor Efforts in LICs}

We have underscored the difficulties posed for LIC fiscal policy managers when there are uncertainties as to the timing, duration, magnitude, content, and conditionality of aid. For some countries, this is exacerbated by the large number of donors, each with their own procedures and reporting requirements, and by the multiple sector managers with whom they interact (often independent of the fiscal managers in the ministry of finance). The greater the certainty, the easier the task of a government in formulating and managing its budget and fiscal policy framework. And the more effective donor coordination, the higher the likely overall productivity of the aid and the less taxing it will be on the limited capacity of an LIC for aid and budgetary management. Aid flows can never be the equivalent of domestically mobilized resources in terms of their fungibility or degree of certainty. But there is significant scope for both donors and recipients to facilitate greater certainty and efficiency in the delivery of aid.

The international donor community has recognized that external assistance has contributed to the fragmentation of LIC budgets and the volatility of revenues. ${ }^{44}$ The Paris Declaration on Aid Effectiveness articulated five key partnership commitments, with a principal focus on recipient country ownership, alignment with recipient country priorities, harmonization of donor efforts, management for results, and mutual accountability. Yet this initiative, even if speedily implemented and broadened to include the multiple other providers of external resources, does not address the lack of certainty as to the duration of external assistance. Several further steps are required:

- Longer donor commitments: Some donors are moving in this direction (witness the United Kingdom Department for Financing International Development (DFID) recent efforts in Ethiopia, Malawi, and Rwanda (as described in Box 3). The EU has moved

${ }^{44}$ See Bulir and Hamann (2006) 
to delineate a portion of aid commitments - the fixed tranche disbursement - that would only be based on a basic framework of cooperation and satisfactory macroeconomic performance (and not be subject to sharp reversals in the event of poor performance). Only disbursement of the variable tranche would depend upon performance in terms of agreed results-based outcomes. Even with political concerns, there is an expectation of some dialogue and engagement before any suspension of aid.

- Greater efforts by donors to understand better how to translate the provision of aid into development outcomes. Grants should be less tied to specific projects, channeled through the budget, and coordinated better with recipient country development frameworks and the aid of other donor countries. Donors could seek to disburse aid in a countercyclical manner and find ways to respond more quickly and more efficiently in the event of large adverse shocks. Donors should expeditiously provide reliable and complete information on flows of development assistance in order to facilitate their incorporation into budgets and medium-term fiscal plans. This also entails presenting the data in a format compatible with internal government systems.

- Increased provision of technical assistance to strengthen PFM is critical if higher aid flows are to be managed and absorbed effectively. Donors have stepped up efforts to improve the general diagnosis of PFM weaknesses in LICs, developing tools such as the Public Expenditure and Financial Accountability (PEFA) framework in order to provide a basis for in-depth diagnostics, focused recommendations, and coordinated assistance to tackle key deficiencies. ${ }^{45}$ PFM reforms are focusing on improving budget preparation, presentation, execution, control, and reporting.

Enhancement of treasury operations and accounting procedures also rank high on the PFM agenda. Most approaches emphasize that PFM reform should be country-led and require donor harmonization and alignment around the country strategy with a focus on monitoring and results, often through IMF conditionality. However, institution-building is a medium- to long-term endeavor. It can be costly. ${ }^{46}$ Its durability is often contingent on the presence or absence of a reform-minded permanent secretary or budget director in the ministry of finance. Sustained country and donor commitment, combined with focused reform implementation, appropriate sequencing, and realistic expectations on the rate of improvement, are essential to overcome capacity limitations.

\footnotetext{
${ }^{45}$ This approach has recently been elaborated by the PEFA group, in consultation with the OECD-DAC Joint Venture on Public Financial Management. PEFA is a partnership program between the IFIs and a number of donors. See: http://www.pefa.org.

${ }^{46}$ It should also be recognized that some PFM reforms can be expensive, with such reforms themselves absorbing significant external aid resources. Cases in point are Tanzania, where approximately $\$ 85$ million was spent over five years on PFM reforms, Kenya, which has proposed a \$119 million reform plan, and Uganda, which has proposed a $\$ 56$ million plan.
} 
Box 3. Developing Long-Term Partnerships: The U.K. Experience

The United Kingdom has been at the forefront of efforts to provide developing countries with predictable longterm assistance. In addition to an extensive involvement in multi-donor groups that coordinate aid, particularly budget support, the U.K.'s DFID has signed long-term bilateral development partnership agreements with a number of countries in Africa. These are underpinned by a published Memorandum of Understanding (MoU). These MoUs provide a transparent framework for cooperation between the two governments, based on a range of economic, political, and governance commitments, with a duration of up to 10 years. MoUs typically indicate a preference and commitment to provide general budget support, based on an evaluation of performance, and stress the need to improve donor alignment and harmonization and country financial management and reporting systems.

In Rwanda, under the MoU signed in February 2006 the United Kingdom committed to provide at least $£ 460$ million in development assistance over the next 10 years. The MoU sets out shared commitments as well as the commitments each partner has made to the other, the monitoring and review process, a clear basis for discussion and dialogue, and the circumstances under which development assistance would be interrupted or reduced. The intention is to provide at least two-thirds of the support through a rolling program of budget support.

A similar 10-year MoU was signed in 2003 in Ethiopia, which stated the United Kingdom's intention to provide a substantial proportion of development assistance as direct budget support with an indicative figure provided for the subsequent three years. However, because of concerns over the political situation, the United Kingdom halted its budget support in 2006, but reiterated its commitment to continue support to the people of Ethiopia in their fight against poverty. Alternative methods of aid delivery are currently being investigated with the government and other donors, with an emphasis being placed on tighter financial reporting and stronger local accountability.

DFID is engaged in a variety of programs in Malawi, of which the most innovative is a $£ 100$ million six-year program to support the health service through a so-called Sector Wide Approach (SWAp). The concept is intermediate between traditional project and program support in the sense that resources are an integrated part of the government's budget for recurrent spending. But their use is defined within an agreed programme of work and is guaranteed for a six-year time span (subject to conditions on government cofinancing). A key element of the SWAp arrangement is to provide salary top-ups for health sector employees in order to attract and retain qualified staff. The program is a pooled arrangement with the World Bank and Norway. The MoU was signed in 2005.

It is premature to assess the impact of such long-term bilateral agreements. The MoUs tend to be much broader in scope, including more political commitments, than the more common multi-donor groups that are increasingly being formed around the delivery of budget support. However, these are not exclusive instruments, as the MoUs also provide an explicit link to existing or emerging formalized partnership agreements with other donors and seek to utilize their common performance monitoring frameworks. However, this will complicate the evaluation of the MoUs, in terms of improved predictability and reduced volatility, as it may be difficult to separate their impact from that of the multi-donor partnership arrangements.

- $\quad$ Simple, formalized partnership agreements: These can help to harmonize and streamline aid delivery. Where the relationship between donors and the recipient is advanced, a "joint partnership framework" can outline the basic principles of donor collaboration, using a common "performance assessment framework" (PAF) for reviews and disbursements (e.g., recent examples exist in Mozambique, Tanzania, Ghana, and Burkina Faso,) see Boxes 4 and $5 .{ }^{47}$ Such agreements can facilitate joint

\footnotetext{
${ }^{47}$ For an evaluation of PAFs in these countries, see Lawson, Gerster, and Hoole (2005)
} 
monitoring of program support by donors and recipients, managed according to a set of predefined common principles, even when disbursement decisions remain subject to individual donor decisions. The IMF's participation as an observer to these arrangements has helped provide a link to the macroeconomic framework. ${ }^{48,49}$

Box 4. The Impact of Donor Coordination on Aid Management: Tanzania’s Experience

By the early 1990s, Tanzania's relationship with donors was strained due to deteriorating policy and fiscal performance and its failure to collect counterpart funds for donor-supported programs. Donors were also concerned about corruption and budget mismanagement. The government saw donors as inappropriately intrusive and unwilling to deliver on their promises. In 1994, an independent group of experts was asked to recommend how to improve donor coordination. Inter alia, it recommended the government formulate clear medium to long-term national development priorities and undertake necessary reforms in public services and financial management. It urged donors to better coordinate and harmonize their development assistance, including practices and procedures to increase the predictability of aid. These recommendations initiated a process to redefine the relationship between the government and donors and the management of aid on the basis of principles of national ownership, government leadership, harmonization, and alignment.

One outcome was the launching of the Tanzania Assistance Strategy (TAS) in 2002. An Independent Monitoring Group was set up in 2002 to monitor the performance of the government and donors, and to develop a TAS action plan. Actions were grouped in four priority areas: increasing the predictability of aid flows; integrating external resources into the government budget; harmonizing and rationalizing processes; and improving national capacities for aid coordination and external resource management.

Donor coordination has subsequently improved. The government has strengthened PFM and accountability. Quarterly reports on fiscal performance have greatly improved transparency in policy formulation and implementation. Quarterly consultations on sector programs have provided an opportunity for donors to monitor program implementation and participate in program design. Predictability of external resources has improved and external funds have increasingly been integrated into the budget, thereby strengthening government ownership over resource allocation. As for the donors, they have increasingly aligned their activities with national systems and processes.

Weaknesses nevertheless remain in aid management. Parallel systems and procedures for delivering, managing, monitoring, and evaluating development assistance as well as multiple missions, meetings, and analytical studies have remained burdensome for the government. Furthermore, the still widespread provision of off-budget financing, most notably for projects, has impeded strategic resource allocation in the national budget process as well as transparency and domestic accountability in the utilization and performance of external resources. To address these challenges the government and donors recently launched a Joint Assistance Strategy (JAS) (March 2006) to further reduce the still high transaction costs arising from the pursuit of different strategies with multiple and often overlapping processes. It also aims at enhancing national ownership and government leadership of the development process and shifting government accountability from donors to domestic stakeholders.

${ }^{48}$ Many of the most advanced arrangements are still being refined, mainly by reducing the number of indicators or PAF conditions, to ease implementation-for example in Ghana the PAF comprised 29 indicators in 2006, down from 39 in 2005, while the performance tranche disbursements are linked to a sub-set of only 10 indicators.

${ }^{49} \mathrm{Op}$. cit. The need to simplify donor policies and to encourage collaborative behavior was one of the commitments made by donors at the Rome conference. 
- $\quad$ But joint partnership frameworks can take time before they demonstrate their success in improving the predictability and effectiveness of aid. ${ }^{50}$ For example, in the first and second years of operation of the Poverty Reduction Budget Support arrangement in Tanzania, budget support was still the most unpredictable of all government revenue sources, being 22 percent and 32 percent below budgeted levels, respectively. In the Tanzania case, budget support only became more certain in the third year, falling only 2 percent below budgeted levels (FY2003). Incorporating explicit targets for predictability in the PAFs might also accelerate this process.

\section{Box 5. The Benefits of Donor Coordination: The Case of Burkina Faso}

Through the 1990s, Burkina Faso, which received substantial aid flows from the international donor community, was plagued by several shortcomings associated with the delivery of these resources. Above all, lack of predictability and continuity in aid complicated fiscal programming and management. Excessive conditionality and lack of coordination among donors further complicated policymaking. The government struggled to satisfy the various donors and cope with frequent and demanding donor missions. As a result, ownership of reforms as part of donor conditionality was often weak.

In 2001, under the leadership of the EU, six development partners decided to provide annual budget support to Burkina Faso, and strengthen their coordination through a joint budget support group. The World Bank, the largest provider of budget support, first joined the group as an observer. Declared priorities of the group were to (i) improve predictability and regularity of budget support; (ii) obtain greater ownership by the government in the implementation of the PRS as identified in the 2000 PRSP; and (iii) strengthen coordination between partners through joint evaluations of the government's progress with regards to poverty eradication. The group met frequently, keeping track of committed and disbursed aid. As a consequence, predictability of budget aid improved markedly, facilitating fiscal programming for the government. Remaining aid volatility could largely be attributed to the few donors who hadn't joined the partnership.

In 2005, the group harmonized donor interventions even further, reflecting an assessment of their collaboration by the minister of finance. It now includes all major donors of budget support, particularly the World Bank and the African Development Bank (AfDB). A jointly approved matrix of measures and indicators forms the basis for budget support disbursements, in tandem with IMF and the group's own periodic program reviews. This matrix presents a breakthrough in aligning donor conditionality.

Traditionally the EU advocated an indicator framework with a longer-term perspective, whereas the World Bank disbursed its support on the basis of shorter-term policy action triggers. Moreover, the leadership for budget support coordination is now assumed by the government, rather than by donors. The minister of finance is the group's president, managing its activities jointly with a representative of the donors.

Some challenges remain. More harmonization in the timing of disbursements is still needed. Some donors favor performance indictors that are lagged by one year, whereas others would like to disburse in the yearly budget period itself as an incentive for compliance with conditionality for the government. Donors also need to disburse early in the budget cycle, rather than during the last months of the year, and provide multiannual aid commitments.

\footnotetext{
${ }^{50}$ Bulir and Hamann (2006).
} 


\section{B. Recipient Country Actions}

Recipient nations can enhance their capacity for managing fiscal policy in the context of scaled up aid flows. This is particularly relevant if there is an increased share of program assistance and sectoral support relative to projects. A number of approaches are possible:

- Strengthening the capacity to monitor and manage development funds: Many countries have created dedicated functional units within the ministry of finance to record and monitor the performance of external grants and debt, e.g., Ghana's Aid and Debt Management Unit or Tanzania's External Finance Department. While creating such units may be helpful, e.g., for including commitment information in projections (see below), the move towards budget support also requires coordination throughout the budget process, including with the line ministries responsible for delivering the services on which performance conditionality is commonly based. Specific financial regulations and procedures are often needed to support such coordination. ${ }^{51}$

- Integrating donor information in fiscal data: In order to assess overall resource availability and allocate resources in line with policy priorities, governments should integrate aid flows, on both an ex ante and ex post basis, within the budget so that they can be programmed alongside domestic resources. While program support, loans, and debt relief are channeled through the budget, considerable aid is still delivered as discrete projects, with funds disbursed through separate arrangements. This occurs even when the agency is part of government. Many countries have established dedicated aid management information systems to supplement their accounting systems, with information reported by donors and/or line agencies. However, even when standard reporting formats have been agreed (e.g., Ghana, Uganda, and Tanzania), this problem of separate data reporting can persist (see Box 6).

- Improving the realism of the budget: To be a credible policy tool, the annual budget needs to be based on realistic projections of available resources and expenditures. Governments usually need to adjust donor commitments to provide a better indication of likely disbursements. As an interim measure, countries with a long track record of donor assistance can scale donor pledges with 'discount' factors. For example, Uganda applies a discount factor on donor budget support set at the average level by which disbursements have fallen short of commitments over the last five years (currently around 35 percent). This could also be refined for differences

\footnotetext{
${ }^{51}$ A major challenge is the highly fragmented nature with which aid flows are sourced and managed within line ministries. Line ministries themselves may have difficulty limiting the pressures for absorbing aid for specific projects, and the possibility of organizing a coherent and integrated sectoral strategy is made more difficult by the effective earmarking of a substantial share of a ministry's budget. This makes a rational allocation of budgetary resources by the central budgeting agency even more complex.
} 
across donors, but should be seen as a second-best solution to improving the reliability of donor commitments.

Box 6. Managing and Accounting for Aid Not Channeled through the Budget

The tendency of donors to bypass regular government procedures is ostensibly to speed up project preparation and disbursement when local capacity remains weak; to avoid cumbersome or ineffective financial management and procurement procedures that do not meet required accountability or transparency standards; and to avoid corrupt practices. However, incorporating this information into budget processes remains problematic for many countries, even when dedicated systems have been established for this purpose (as illustrated below).

- Afghanistan continues to face a complicated post-conflict situation. Tax and other revenue covers less than half of recurrent costs and direct external assistance is extremely large (estimated at around 25 percent of GDP for 2006/07 with an additional 14 percent channeled through the budget). In order to manage this process, the authorities have developed an overarching policy framework with programs overseen by Consultative Groups headed by a lead ministry and incorporating the relevant donors. The budget department of the Ministry of Finance, supported by donors, maintains a database that measures donor pledges, commitments, and disbursements. This information has been reported ex ante in budget documents (and called the External Budget) and ex post on an ad hoc basis. However, donor reporting has been sporadic and often not in a format consistent with the government's requirements, making it difficult to report spending by province or to incorporate robust projections and outturns in budget documents. Despite considerable donor assistance, the resources devoted to coordination, recording, and reporting have been considerable and have occasionally diverted resources away from efforts to strengthen other areas of PFM, including budget execution. This is one factor that has contributed to the very low implementation rates for major programs.

- Tanzania has made a concerted effort to encourage donors to channel support through the PFM system. The share of annual funding going to either untied budget support or basket funds established for sector-specific activities in 2004/05 was expected to account for 56 percent of total assistance (excluding HIPC relief), compared to 39 percent in 2000/01. Consequently, reporting on donor-funded activities has significantly improved. The authorities have also tried to integrate project spending into budget documents and procedures. There are two forms of budget data: (1) core data is based on the domestic accounting systems; and (2) augmented data, which includes additional data on foreign financed projects from the External Finance Database. Augmented data is used by policymakers for budget projections of foreign project financing and for assessing the availability of financing for achieving fiscal policy objectives, as well as for medium-term budgetary projections. Over the past several years, the augmented data has been used by the IMF for program monitoring purposes. However despite these efforts, the bulk of donor-financed projects remain outside the core PFM system, with only an estimated 25 percent of project expenditures reported to the Accountant-General in $2002 / 03 .^{52}$

\footnotetext{
${ }^{52}$ See Tanzania, 2004.
} 
- Strengthened of fiscal reporting: Appropriate budgetary classification systems need to be in place, computerization encouraged, and efforts made to incorporate subfederal levels of government in the fiscal reporting framework (see IMF, 2005a).

- $\quad$ Clear leadership: Regular in-country meetings with donors under government leadership, dissemination of information on the progress of reforms, and clarification of domestic needs at both the national and sectoral levels can enable donors to better adapt their future programs to their comparative advantage, can greatly improve information flows, and can enable donors to better adapt their future programs to their comparative advantage.

\section{Strengthening the Medium-Term Fiscal Orientation}

Section II highlighted the analytical importance, for policy and budget formulation, of having a medium- to long-term perspective on the fiscal framework. Section III emphasized the importance of such a framework for developing a shared strategy with donors and identifying the main fiscal risks and mitigating strategies.

Three basic stages of institutional development have been identified for multi-year budgeting: ${ }^{53}$ (i) a medium-term fiscal framework provides a statement of fiscal policy objectives and sector strategies and a set of integrated medium-term macroeconomic and fiscal targets and projections; (ii) a medium-term budget framework (MTBF) incorporates projections of revenues and of spending by individual agencies that allocate resources in line with strategic priorities, consistent with the overall fiscal objectives of the MTFF; and (iii) a medium-term expenditure framework (MTEF), which extends the analysis of expenditure further, with more detailed sectoral costing and performance measures (possibly including activity and output-based budgeting) (Lawson and Jones, 2001). ${ }^{54}$ MTEFs typically lack revenue projections.

In countries that have the capacity, the expenditure path identified in the MTFF should be the basis for a three-four year-horizon rolling MTEF. Ideally, both the MTFF and the MTEF would then be aligned with the yearly budget exercise, and ultimately, budget execution. While for many LICs this approach might still prove very ambitious, such alignment would facilitate the channeling of scaled-up aid and debt relief toward spending programs geared to reaching the MDGs. While the yearly budget exercise is by definition subject to tighter constraints, it should strive to converge with the fiscal path identified in the MTFF and resulting MTEF.

\footnotetext{
${ }^{53}$ See Lawson (2000), Boex et al (1998), Obidegwu (2005), and Holmes and Evans (2003).

${ }^{54}$ Indeed, in some countries (notably Ghana and Tanzania), the MTEF has gone beyond the provision of a medium-term projection framework and become almost the budget itself.
} 
Equally important, to ensure that the alignment of budget planning with budget execution allows for robust cash-flow planning, countries should be encouraged to move from cash rationing to cash management.

However, in countries where key aspects of budget management remain weak, a multi-year framework alone will not be able to deliver improvements in donor coordination or PFM.

Indeed, if annual budgets lack realism or where PFM systems are deficient, a complex MTEF may be counterproductive and divert attention and limited administrative capacity away from more basic PFM reforms (see Box 7) ${ }^{55,56}$ An intermediate option is to move to a MTBF. Bevan (2006) has noted that such a move means adding a mechanism for allocating discretionary resources between competing spending agencies, again over a multiyear horizon. While an informed judgment on allocations for the out-years can be a demanding task, he notes that a mechanistic start is possible, with some sectors strategically (and arbitrarily) targeted to grow at a higher rate than the average, with others maintaining their share and others declining. Over time, as the MTBF process is updated in a rolling framework, the system can evolve away from this mechanical start.

In the event that even a MTBF would also strain a government's PFM capacity, donors should assist governments in developing the capacity to elaborate appropriate MTFFs. Particular attention should be given to avoiding a dichotomy of current expenditure versus capital expenditure. In countries with limited administrative capacity, an alternative to a full-fledged MTFF could be a limited set of sectoral scaling-up scenarios, guided by the principles outlined above. The focus would be on those individual sectors (e.g., the social sectors) likely to be recipients of significant aid flows. In such countries, heavy focus should be placed on addressing weaknesses in the key components of a PFM system, viz., a reliable and timely PFM data base, a good budget classification system, basic accounting procedures, a sound reporting system, a unified budget, and a treasury single account.

\footnotetext{
${ }^{55}$ See Lawson (2000) and World Bank (2005).

${ }^{56}$ Bevan (2006) notes the difficulties that arise in introducing an extended version of the MTEF, including the sheer scale and complexity of what is involved, such as radical changes to the budget classification system and the introduction of new modalities, e.g., IFMIS. He emphasizes that even partial success in introducing an MTEF requires a "careful matching of demands to capacity and to the rate at which capacity can be built" and "palpable incentives to induce line ministries to cooperate."
} 
Box 7. Ghana: The Medium-Term Expenditure Framework

The MTEF was introduced in Ghana with the 1999 budget in order to provide a methodology for costing objectives in detail and prioritizing them to fit within the available resources, both between and within sectors. It responded to the weakness of the national and sectoral objectives of the Vision 2020, introduced in 1994 to set out long-term goals, and the five-year plans (first introduced to cover the period 1997-2001). ${ }^{57}$ The MTEF includes a budget for the upcoming year and indicative estimates for the succeeding two years.

An overambitious reform agenda and difficult economic circumstances hindered the MTEF's introduction. The MTEF was one component of a broad program of donor-supported assistance designed to improve Ghana's PFM. These included the introduction of: a new computerized integrated financial management system; a computerized integrated personnel and payroll management system; civil service reform; a move towards output measures of budget assessment; and a decentralization program. An Interim PRSP was also produced in 2000. The introduction of the MTEF coincided with the change in government in December 2000. External shocks (as witnessed by a dramatic deterioration in Ghana's terms of trade) and weak macroeconomic management also caused large divergences between budgets and outturns, considerably reducing the credibility of the MTEF. Progress was also impeded by the poor PFM system —in 2001 a joint World Bank-IMF assessment concluded that Ghana met only one of 15 benchmarks, ranking it among the lowest and most in need of substantial upgrading. ${ }^{58}$

Despite the considerable resources devoted to the MTEF and PFM reforms, many of the original objectives have yet to be achieved. A repeat review of the performance of the PFM systems in 2004 concluded that the figures for the MTEF's outer two years continued to be derived by applying uniform growth factors to both domestic and donor-financed spending respectively. The MTEF therefore did not reflect the detailed costing work that had been undertaken in priority sectors for ongoing and planned programs, nor did it reflect changes in sector prioritization based on Ghana's Poverty Reduction Strategy. The apparently mechanical approach to the MTEF for the two out-years is also a concern, as these figures are presented as "discretionary expenditure ceilings" that, if adhered to, would lock spending into the pattern of the 2004 fiscal year, making the budget a purely incremental exercise.

The poor performance of the MTEF does not argue against a medium-term fiscal perspective. Rather, the MTEF concept needs to be further developed to make it a realistic strategic tool for planning and budgeting. In the short-term, this may mean simplifying the budget process that is presently designed as both a top-down process (to maintain fiscal discipline and allocate resources in line with priorities) and a bottom-up process (in which ministries, departments and agencies prepare strategic plans and activity-based budgets). In support of the objectives of the MTEF and to improve coordination around policies and budget support, the main donors have also created a Multi-Donor Budget Support group that has put considerable emphasis on the MTEF and PFM reform program.

\footnotetext{
${ }^{57}$ See Foster and Zormelo (2002)

${ }^{58}$ See the HIPC Initiative Assessment and Action Plan exercise conducted by the World Bank and IMF. This exercise was repeated in 2004, when Ghana's PFM systems were assessed as meeting seven out of the sixteen benchmarks. See: www.worldbank.org
} 


\section{Strengthening the Institutional Mechanisms for Monetary and Fiscal Policy Coordination}

Section II emphasized the importance of close coordination of monetary and fiscal policy in the context of scaled-up aid. Coordination should be a continuous process. It is needed in designing a medium-term financial programming framework, in annual budget preparation, and day-to-day operations. Achieving such coordination does not imply that the central bank would lose its independence. Rather, it argues for much greater interaction between the central bank and the fiscal authorities in terms of sharing information on budgetary plans and on the timing of expected receipts of aid disbursements and spending. The objective is to ensure that the central bank, in its management of monetary policy, can take account of the impact of fiscal operations, particularly in situations where the magnitude of aid flows and their liquidity effects may be large. This enhanced coordination would be relevant independent of whether the central bank is running a flexible or fixed exchange rate policy (and in the latter case, whether or not part of a currency union).

Institutional measures to facilitate improved fiscal-monetary coordination include better cash forecasting and management, often preceded by the consolidation of government bank accounts into a treasury single account structure; enhanced monitoring and forecasting of the cash flows of large and often lumpy donor financed projects; initiatives to smooth intra-year revenue and spending profiles; and the development of formal operational agreements and communication arrangements between the central bank and ministry of finance, particularly with regard to the foreign exchange strategy. In addition, better coordination with donors might prevent the concentration of disbursements in the last quarter of the year.

\section{E. Independent Audits of the Fiscal Policy Framework}

Considering the fiscal challenges posed by a scaling up of aid, LICs might consider fiscal process innovations observed in some industrial countries that provide an independent perspective on the government's management of fiscal policy. Non-politicized fiscal agencies can enhance transparency and accountability, providing stronger incentives for efficiency and effectiveness, as well as some reassurance to donors. Approaches that have been tried include the creation of an independent evaluation agency and a strengthening of an existing audit agency by a broadening of its mandate beyond the ex post auditing of outturns. The terms of reference for such a unit would be to (i) evaluate the assumptions used in medium-term budget plans; (ii) monitor the implementation of fiscal rules (viz., to identify slippages and suggest corrections); (iii) monitor and assess coordination mechanisms between authorities and donors; and (iv) carry out real-time analysis of aid and expenditure flows, tracking specific capacity bottlenecks. 


\section{Conclusions}

Recent initiatives to relieve many LIC governments of their debt obligations and to scale up aid should allow for an expansion of fiscal space for programs to spur long-term growth and reduce poverty. But they also pose challenges for the design of a fiscal framework that fosters a sustainable delivery of enhanced public services and strengthened infrastructure, while still ensuring a credible commitment to fiscal prudence. The challenges arise for many reasons. First, governments face uncertainties about the aid itself. How much additional aid will be forthcoming? How will it be structured in terms of its composition? How conditional will it be? What will be its phasing? And for how long are donors willing to make commitments of enhanced aid? A second set relates to the complexities of development itself - the challenges of using aid in ways that remove key bottlenecks to growth, foster high productivity, and achieve the MDGs. Third, with the additional fiscal space afforded by debt relief, governments will have to think carefully about how much and how fast new debt can be accumulated in support of growth initiatives, even if much of the debt is on concessional terms. And finally, there is the issue of whether absorption of scaled-up aid will lead to a real appreciation of the exchange rate, and with what effect? Countries will have to be satisfied that aid can foster higher productivity and sustained competitiveness.

This paper has sought to examine how governments can formulate a fiscal framework that is ambitious in its goals for absorbing additional aid, prudent in terms of the sustainability of programs and government finances, and supportive of macro stability. There are six principal points to emphasize.

First, fiscal policy should be formulated in the context of an ambitious MTFF that is based on an aid scenario that is both ambitious yet realistic. Such a policy framework should embody higher domestic revenue mobilization in order to facilitate an eventual graduation from aid dependency. At a minimum, scenarios should be prepared for those sectors likely to receive significant additional aid. Such an MTFF should be linked to the annual budget and, if a country has the institutional capacity, to an MTEF.

\section{Second, an important fiscal policy objective should be the assurance of a stable expenditure path, which would become the principal fiscal anchor. Volatility in spending programs in the past, whether related to volatility in aid flows or exogenous shocks, has never been neutral across spending programs and input categories and has invariably been damaging to the productivity of projects and programs. The fiscal policy framework should avoid disruptive cutbacks in nonwage spending in sectors and in necessary O\&M, as well as the stalling of projects (recognizing that a permanent shock will probably require a downward adjustment in spending). A important corollary of this approach is that one might then need to accept some variability in the domestic financing requirements of the government - principally financed by a buildup or drawdown of government reserves- reflecting volatility in aid flows and the effort to smooth expenditures.}


Third, the composition of expenditure matters in terms of the pursuit of a sound fiscal policy framework. This is particularly the case if much of the increase in aid is intended for the expansion of a few key sectors. Expanding the share of government spending dedicated to programs that are of a recurrent nature, which are difficult to cut back, or which are subject to clear absorptive capacity limits, requires a more prudent posture in terms of facilitating a smooth expenditure path than a spending program that is enhanced through discrete capital projects. Equally, the macroeconomic issues in absorbing aid are very much determined by whether the expansion in aid is used for the purchase of nontradeables or tradables and the extent to which the aid can enhance productivity and remove supply bottlenecks. The aggregate expenditure target consistent with financing that is available may thus need to be modified - indeed possibly reduced - to take account of the composition of expenditure (and also possibly the sources of financing if heavily reliant on debt).

Fourth, a significant scaling up of aid- and debt-financed spending programs calls for enhanced attention to policies of risk management. The uncertainties involved - both in terms of the short-run volatility and long-run uncertainties of aid and the risks of a rising debt ratio - argue for risk management to be a central factor in the construction of the fiscal policy framework. Strengthened practices for assessing risk as well as policies for self-protection and self-insurance are essential in formulating a sound medium-term macroeconomic framework. The paper emphasizes three key elements of such an approach: (i) supplementing existing debt sustainability assessments with medium-term vulnerability analyses under alternative scenarios; (ii) policies of self-protection; and (iii) policies of self-insurance centered on an explicit policy of higher reserve accumulation related to the degree of vulnerability of the budget, given its composition and sources of financing.

Fifth, a strengthening of institutions is vital if governments are to manage the absorption of scaled-up aid and implement expanded service delivery programs and capital expenditure projects. This paper reaffirms the importance of strengthened PFM and enhanced efforts toward output-focused (and medium-term framed) budgets. But it also highlights that additional processes must be elaborated and institutions strengthened if governments are to manage and implement fiscal policy for development more effectively. In particular, countries should bolster their capacity to monitor and manage the terms and duration of prospective aid commitments.

Sixth, donors will play a critical role in determining whether their financing of additional fiscal space can be translated effectively by recipient countries into productive and efficient development programs and projects. This entails enhanced donor coordination efforts and a greater willingness to make long-term predictable commitments. Donors should be encouraged to facilitate or finance initiatives that contribute to the implementation of smoothing or buffer mechanisms in exchange for well-designed medium-term expenditure programs in support of the MDGs. The latter may derive from either support for reserve accumulation efforts by recipient governments or donor pooling of some reserves. 
Two final points. First, this paper has largely focused on the issues posed for countries seeking to absorb, to the maximum extent, additional aid resources. A country may believe that it cannot productively absorb more aid without an adverse impact on its real exchange rate and its long-term growth prospects and this decision by an LIC government needs to be respected by the donor community.

Second, donor countries may ultimately prove less generous than anticipated. Witness the expansion of ODA flows in 2006, which largely reflected debt relief for Iraq and Nigeria. Much of the expansion of aid flows to LICs was largely focused on a few sectors and was heavily linked to vertical initiatives, particularly in relation to HIVAIDS treatment and prevention programs. Coming years might also see aid focused on the scaling up of particular program initiatives, but without a substantial scaling up in aggregate aid levels. Many of the issues discussed in this paper would still be germane. Others, such as the extent to which governments would confront macroeconomic pressures, particularly on the real exchange rate, would be less relevant. However, governments will still need to grapple with deciding how and whether to accommodate the implied imbalances that can arise across sectors because of donor preferences. Effectively, the expansion of government expenditure programs may become inconsistent with the overall strategy embodied in the PRSP. Governments will then need to decide whether to accept the additional aid and accommodate such imbalances or seek to exploit fungibility as much as possible in budgetary allocations. 


\section{REFERENCES}

Adam, C., and D. Bevan, 2001, Fiscal Policy Design in Low income Countries, WIDER Discussion Paper No. 2001/67 (Helsinki: World Institute for Development Economics Research)

Bevan, D., 2006, Medium Term Frameworks: Fiscal, Budgetary and Expenditure (powerpoint presentation).

Boex, L., J. Martinez-Vasquez, and R. McNab, 1998, "Multi-year budgeting: A review of International Practices and Lessons for Developing and Transition Economies," Working Paper 98-4 (Atlanta: Georgia State University, International Studies Program).

Bohn, H., 1998, “The Behavior of U.S. Public Debt and Deficits," Quarterly Journal of Economics, 113 (August), pp. 949-963.

Bulir, A., and A. J. Hamann, 2003. "Aid volatility: an Empirical Assessment," IMF Staff Papers, No. 50, 1.

— , 2006, "Volatility of Development Aid: From the Frying Pan into the Fire?" IMF Working Paper No. 06/65 (Washington: International Monetary Fund).

Celasun O., X. Debrun, and J. Ostry, 2006, "Primary Surplus Behavior and Risks to Fiscal Sustainability in Emerging Market Countries: A 'Fan-chart' Approach," IMF Working Paper No. 06/167 (Washington: International Monetary Fund).

Celasun, O., and J. Walliser, 2006, "Predictability of Budget and Recent Experience," in S. Koeberle, Z. Stavreski, and J. Walliser in Budget as More Effective Aid? (Washington: World Bank).

Clemens, M., S. Radelet, and R. Bhavnani,2004, "Counting Chickens When They Hatch: The Short-Term Effects of Aid on Growth," Working Paper No. 44 (July) (Washington: Center for Global Development).

Chowdhury, A., and T. McKinley, 2006, "Gearing Macroeconomic Policies to Manage Large Inflows of ODA: The Implications for HIV/AIDS Programmes," Working Paper No. 17 (May) (New York: UNDP International Poverty Center).

Eifert, B., and A. Gelb, 2005. "Improving the Dynamics of Aid: Towards More Predictable Budget Support,” Policy Research Working Paper No. 3723. (Washington: World Bank).

Fatás, A., and I. Mihov, 2006, "Policy Volatility, Institutions and Economic Growth," Working Paper (Paris: INSEAD). 
Fielding, D., and G. Mavrotas, 2005, "On the Volatility of Foreign Aid: Further Evidence," (unpublished); (Helsinki: WIDER).

Foster, M., and D. Zormelo, 2002, "How, When and Why does Poverty get Budget Priority, Poverty reduction Strategy and Public Expenditure in Ghana," Working Paper 163 (April) (London: Overseas Development Institute).

Gupta S., B. Clements, A. Pivovarsky, and E. R. Tiongson, 2003, "Foreign Aid and Revenue Response: Does the Composition of Aid Matter?" IMF Working Paper/03/176 (Washington: International Monetary Fund). Available at http://www.imf.org/external/pubs/ft/wp/2003/wp03176.pdf

Gupta, S., R. Powell, and Y. Yang, 2006, Macroeconomic Challenges for Scaling Up Aid to Africa: A Check List for Practitioners (International Monetary Fund).

Heller, P., 2005a, “Understanding Fiscal Space,” Policy Discussion Paper No. 5/4, International Monetary Fund.

Heller, P., 2005b, "Pity the Finance Minister," Vol. 6, No. 4, World Economics (OctoberDecember), pp. 69-110.

Holmes, M., and A. Evans, 2003, “A Review of Experience in Implementing a Medium Term Expenditure Framework in a PRSP Context: A Synthesis of Eight Country Studies," (London: Overseas Development Institute).

IMF 2003 World Economic Outlook, September, Public debt in Emerging Markets.

IMF 2005a, Update on the Assessments and Implementation of Action Plans to Strengthen Capacity of HIPCs to Track Poverty-Reducing Public Spending, IMF Board Paper, Washington.

IMF 2005b The Macroeconomic of Managing Increased Aid Inflows-Experiences of LowIncome Countries and Policy Implications. SM/05/306.

IMF 2006a, Review of Low-Income Country Debt Sustainability Framework and Implications of the Multilateral Debt Relief Initiative (MDRI) (unpublished). $\mathrm{SM} / 06 / 123$.

IMF 2006b, The Federal Democratic Republic of Ethiopia: Selected Issues and Statistical Appendix (IMF Country Report 06/122).

IMF 2006c, The Federal Democratic Republic of Ethiopia: Staff Report (IMF Country Report 06/159). 
IMF 2006d, The Multilateral Debt Relief Initiative-Progress Report on Implementation IMF Country Report SM/06/116.

Katz, M., U. Bartsch, Malothra, and Cuc, 2004, "Lifting the Oil Curse, Improving Petroleum Revenue Management in Sub-Saharan Africa," (Washington: International Monetary Fund).

Lawson, A., R. Gerster, and D. Hoole, 2005, "Learning from Experience with Performance Assessment Frameworks for General Budget Support" (November) General Budget Support Evaluation (Paris: OECD Development Assistance Committee).

Lawson, A., 2000 "Medium Term Expenditure Frameworks: Panacea or Dangerous Distraction?" Oxford Policy Management Policy Review (May).

Lawson, A., and S. Jones, 2001, "Scaling Up: Issues in Moving from Projects to Programmatic Aid," in T. Johnston and W. Battaile, 2000 Annual Review of Development Effectiveness (Washington: World Bank).

Mattina, T., 2006, “Money isn't Everything: The Challenge of Scaling UP Aid to Achieve the Millennium Development Goals in Ethiopia," IMF Working Paper No. 06/192.

Obidegwu, C, 2005, "The Medium-Term Expenditure Framework: The challenges of Budget Integration in SSA Countries," World Bank Africa Region Working Paper No. 82 (April).

Paris High Level Forum, 2005, Paris Declaration on Aid Effectiveness (OECD).

Tanzania, 2004, HIPC Public Expenditure Management Country Assessment and Action Plan (AAP), prepared by the IMF and World Bank in collaboration with the Tanzanian authorities. http://www1.worldbank.org/publicsector/pe/HIPC/TanzaniaAAP2004.pdf

World Bank (2005), “The Medium-Term Expenditure Framework: The Challenges of Budget Integration in SSA Countries," Africa Region Working Paper Series No. 82.

World Bank, 2006, Fiscal Policy for Growth and Development: An Interim Report prepared for the Development Committee Meeting, April 23 (Washington: World Bank). 
Ethiopia: Assessing the Risks from Revenue Volatility under Scaled-Up Aid ${ }^{59}$

Scaled-up aid and multilateral debt relief pose a number of challenges to fiscal management. First, while debt sustainability is not an immediate concern, it remains important to prevent unhealthy drifts in the debt ratio, especially in economies where large exogenous shocks can easily derail debt dynamics. It is therefore critical to monitor the debt path implied by medium-term fiscal policy plans, and to assess vulnerability to exogenous disturbances. Second, the volatility of aid flows may test the cash management capacities of recipient countries, implying undesirable stop-go spending patterns if the liquidity constraint becomes binding when adverse shocks occur. ${ }^{60}$

To formulate sound advice on cash and debt management policies, consistent information is needed on (i) the expected debt path under alternative fiscal plans, (ii) indicators signaling vulnerability to liquidity problems, and (iii) an assessment of the risks stemming from exogenous macroeconomic and fiscal shocks.

The fiscal Debt Sustainability Assessment (DSA) template provides a useful tool of analysis. First, it lends itself very well to scenario analysis in which staff can simulate the liquidity and debt implications of changing key policy parameters (e.g., the revenue effort) or projection assumptions (e.g., potential output growth or the extent of available grant financing), giving an idea of the sensitivity of fiscal outcomes to these assumptions. Second, the DSA template allows an assessment of the impact of unexpected exogenous shocks on debt dynamics and liquidity indicators, either through stress testing or through randomizing the trajectory of key variables. While stress tests are useful to capture the vulnerability to large temporary shocks on these variables, randomization permits a more explicit and more complete assessment of the risks. Such risk analysis can be conducted under alternative policy scenarios to help shape advice on risk management strategies. For instance, staff can study the impact of varying key policy parameters such as the extent of reserve build-up in the face of aid windfalls or the mix of new financing, reserve depletion, and expenditure adjustment in case of shortfall.

The case of Ethiopia (see IMF 2006b, 2006c) and Mattina (2006), which is based on the Ethiopian authorities' own expenditure plans offers interesting illustrations of scenario analysis. Along with an MDG scenario reflecting an assessment of the country's needs to reach MDGs, staff discuss an alternative baseline scenario in which average growth remains consistent with past performance (about 5 percent per annum instead of 7 percent in the MDG scenario) while aid flows are tied down to levels originally budgeted in 2005/06. In particular, scenario analysis is used to show that, in the MDG setup, replacing a third of the assumed aid inflows with concessional loans would bring the NPV of debt-to-export ratio to the 150 percent ceiling. Although simple scenarios provide useful indications on potential vulnerabilities, a more thorough assessment of the specific fiscal risks arising from scaled-up

\footnotetext{
59 This annex was prepared by Theo Thomas and Xavier Debrun.

${ }^{60}$ Also, the two issues are linked in a potentially vicious way as the new capacity to borrow may encourage countries to finance aid shortfalls and spend windfalls, creating an undesirable deficit bias.
} 
aid can be performed with only minimal adjustments to the existing DSA framework. Illustrations below focus on the impact of aid volatility on sustainability and liquidity.

A common way to analyze risk in the DSA template is to design stress tests. These typically simulate the impact of large (but plausible) transitory disturbances on fiscal outcomes, keeping all other macroeconomic and policy assumptions unchanged. Although that approach has well-known drawbacks, ${ }^{61}$ it provides a good first-order approximation of potential sources of risk to the baseline.

Two stress tests on grants are considered to illustrate the extent to which aid volatility affects sustainability and liquidity. In the first test, growth in real grants is set equal to its historical average minus one standard deviation for 2006 and 2007. To avoid the permanent level effect of such shocks, grants (in real terms) are then assumed to converge back to the baseline path within three years. ${ }^{62}$ The second, and somewhat stronger, test assumes a three-year period of low (in this case, negative) aid growth combined with a five-year catching-up phase (Figure 1). In this experiment, the ceteris paribus assumption implies that the authorities engage in complete expenditure smoothing, and that fully financing the aid shortfall has no impact on GDP growth, inflation or interest rates.

Figure 1. Ethiopia: Stress Tests on Public Sector Grants (2005-2016)

Debt sustainability: NPV of debt-to-GDP ratio

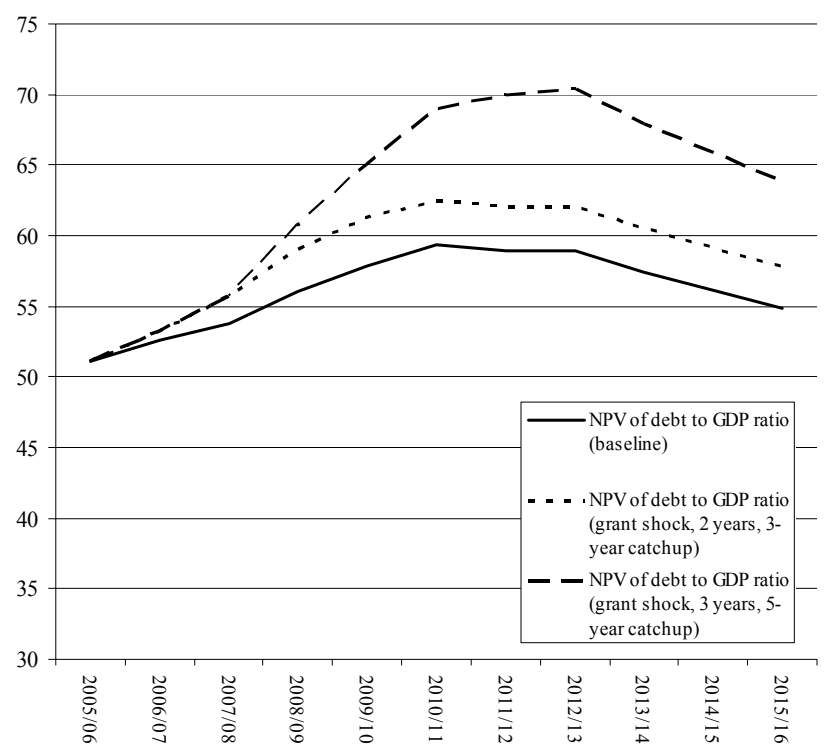

Liquidity: primary balance (in percent of GDP)

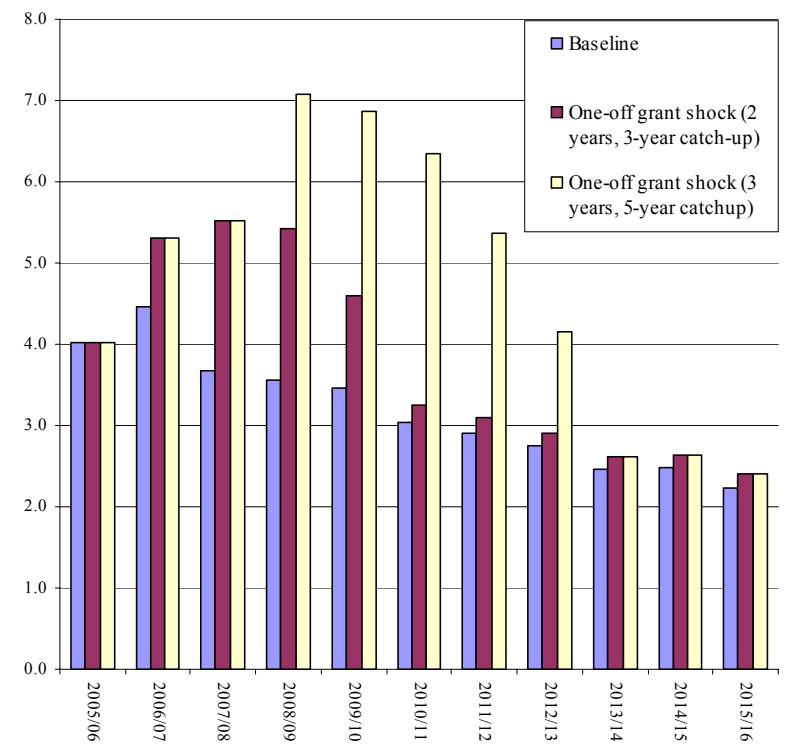

Source: IMF staff calculations

The left-hand panel of Figure 1 suggests that debt dynamics appear to remain manageable even with a fairly significant shock on aid flows. In the worst case scenario, the cumulative

\footnotetext{
${ }^{61}$ See Celasun, Debrun, and Ostry (2006) for a thorough discussion.

62 The extent of this catching-up effect may vary depending on whether the aid shock reflects idiosyncratic donors' behavior or home-grown policy slippages or governance issues.
} 
effect of the disturbance on the NPV of debt peaks at about 10 percent of GDP by 2012 and then declines.

While the MDRI has eased Ethiopia's solvency constraint, the liquidity risk remains high, as evidenced by the sharp increase in the primary deficit (right-hand panel of Figure 1). Under the staff baseline scenario that assumes a modest scaling up of expenditures, the fiscal deficit, excluding grants, is set to widen over the medium-term to over 10 percent of GDP. With a more ambitious MDG-scenario the fiscal deficit excluding grants would increase sharply, peaking in 2010/11 at almost 30 percent of GDP with the resulting annual resource gaps met by a projected increase in external assistance, reaching over US\$6 billion in 2015/16, an increase in per capita terms from about US\$11 in 2004/05 to almost US\$65 by 2015/16. The presence of significant excess reserves in the banking system and high levels of public domestic debt, at over 30 percent of GDP, suggest that the scope for significant increases in domestic financing (even temporary ones) is limited, without recourse to destabilizing inflationary financing. ${ }^{63}$ This severely limits the extent to which the authorities would be able to offset the impact of a grant shock to fund scaled up expenditures through domestic measures.

Additional foreign reserves may also be required to manage the large and possibly lumpy aid flows. Ethiopia's gross official foreign reserves are relatively low by developing country standards, equivalent to around three months of goods and nonfactor service imports in 2005/06 or less than 12 percent of GDP. At current aid levels the ratios of foreign reserves to budgetary grants and domestic debt are around 2.65 and 0.36 , respectively. It is, therefore, unlikely that the above aid shock, which would reduce grant inflows by a cumulative 2 percent of GDP over two years, could be offset by drawing on these reserves. ${ }^{64}$ This suggests that "the management of potentially large and lumpy aid inflows will be a challenge that will require a mix of policy responses depending on the specific circumstances, including a temporary accumulation of reserves, until the aid flows can be productively spent." 65 Under the MDG scenario, the ratio of foreign reserves to budgetary grants would fall even further, to a low of around 0.65 , despite the proposed increase in the reserve levels to over 17 percent of GDP. This would leave Ethiopia's spending plans extremely vulnerable to swings in aid levels as it would be unlikely that sizeable timing mismatches between aid inflows and expected expenditures could be met through a drawdown of foreign reserves. ${ }^{66}$

\footnotetext{
${ }^{63}$ The solvency and liquidity implications of the proposed scaling up of expenditures to meet the MDG targets is discussed in detail in the IMF (2006b). The baseline scenario is taken from the 2006 Article IV consultations with the IMF.

${ }^{64}$ Ethiopia's foreign exchange reserves are held by the central bank and used for monetary policy purposes and are therefore not a direct fiscal substitute for grants. The authorities would also want to maintain a minimum buffer for exchange rate and monetary management.

${ }^{65} \mathrm{IMF}(2006 \mathrm{~b}), \mathrm{p} .17$.

66 The MDG scenario envisages a considerable amount of frontloaded capital expenditure with a high import content. While this mitigates the extent to which domestic liquidity will be injected in to the economy the strategy requires substantial foreign exchange for "lumpy' investments".
} 
The calibration of stress tests is potentially subject to endless debate as regards the plausibility of the specific shock under consideration. To provide a more complete picture of the extent to which grant volatility affects liquidity and sustainability risks, "fan charts" can be constructed. These depicts confidence bands around the median scenario. In Figure 2, zero-mean and normally-distributed transitory shocks are supposed to affect the expected path of real public sector grants (using the historic variance of real grants) ${ }^{67}$ The wider cone represents a mass of probability of 80 percent, whereas the bold dotted lines delineate the 50 percent confidence interval. The charts, which continue to assume that all other policy and macroeconomic assumptions hold, confirm that the liquidity risk — captured by the primary deficit including grants - is a more immediate concern than debt sustainability, although the latter now appears non-negligible.

Figure 2. Ethiopia: Risks Related to Grant Volatility (2005-2016)

Debt sustainability: NPV of debt-to-GDP ratio

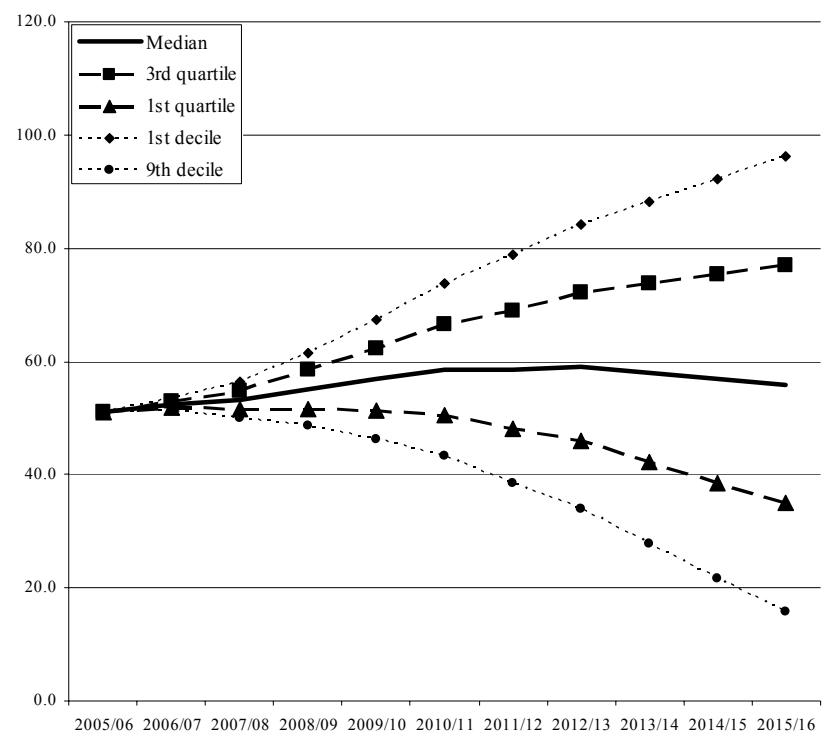

Liquidity: primary balance (in percent of GDP)

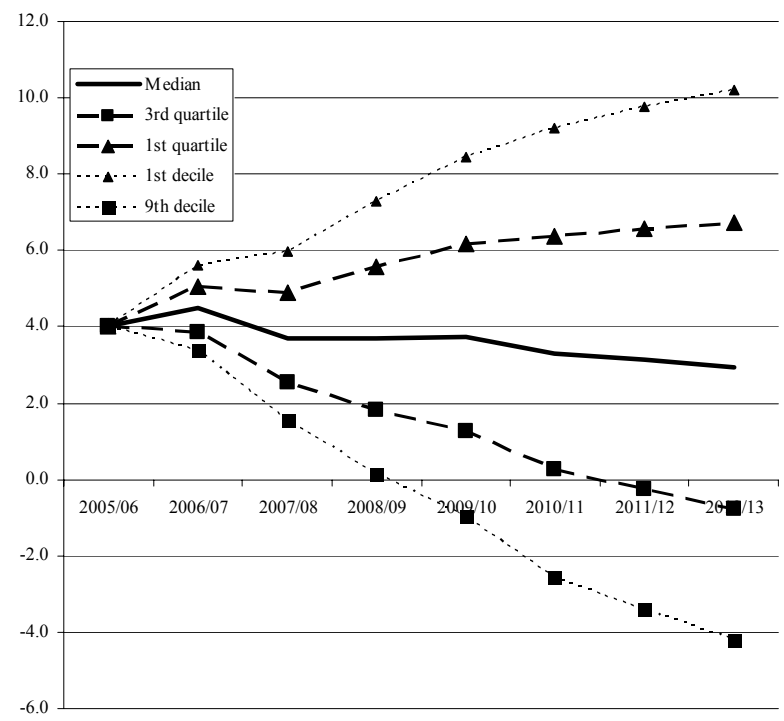

Sources: IMF staff estimates.

A natural policy response to grant volatility is to offset shortfalls by drawing on reserves accumulated when windfalls occur. For a given degree of aid volatility, it is straightforward to see that such policy reduces the risk of illiquidity — and correspondingly the likelihood to adjust expenditure - while moderating public debt fluctuations. The top panel of Figure 3 displays one particular random aid path consistent with the above fan charts. In that specific case, substantial windfalls occur in 2006/07 and 2007/08, bringing aid well above the levels projected in the baseline. The second panel illustrates that the absence of reserve policy is more likely to entail liquidity problems when shortfalls materialize because the latter are fully reflected in the primary deficit. In contrast, a reserve policy aimed at offsetting

\footnotetext{
${ }^{67}$ Disturbances on levels are preferred to those on growth, to avoid any "logarithmic bias" on the resulting aid flows.
} 
differences between actual and projected aid prevents significant jumps in the primary deficits, except by 2011/12, when reserves are exhausted. A smoother debt path also follows (bottom panel of Figure 3). The charts show that alternative reserve policies, whereby part of the aid shocks are reflected in the primary balance, provide less effective protection against liquidity risks. 
Figure 3. Ethiopia: Hypothetical Effect of Alternative Reserve Policies
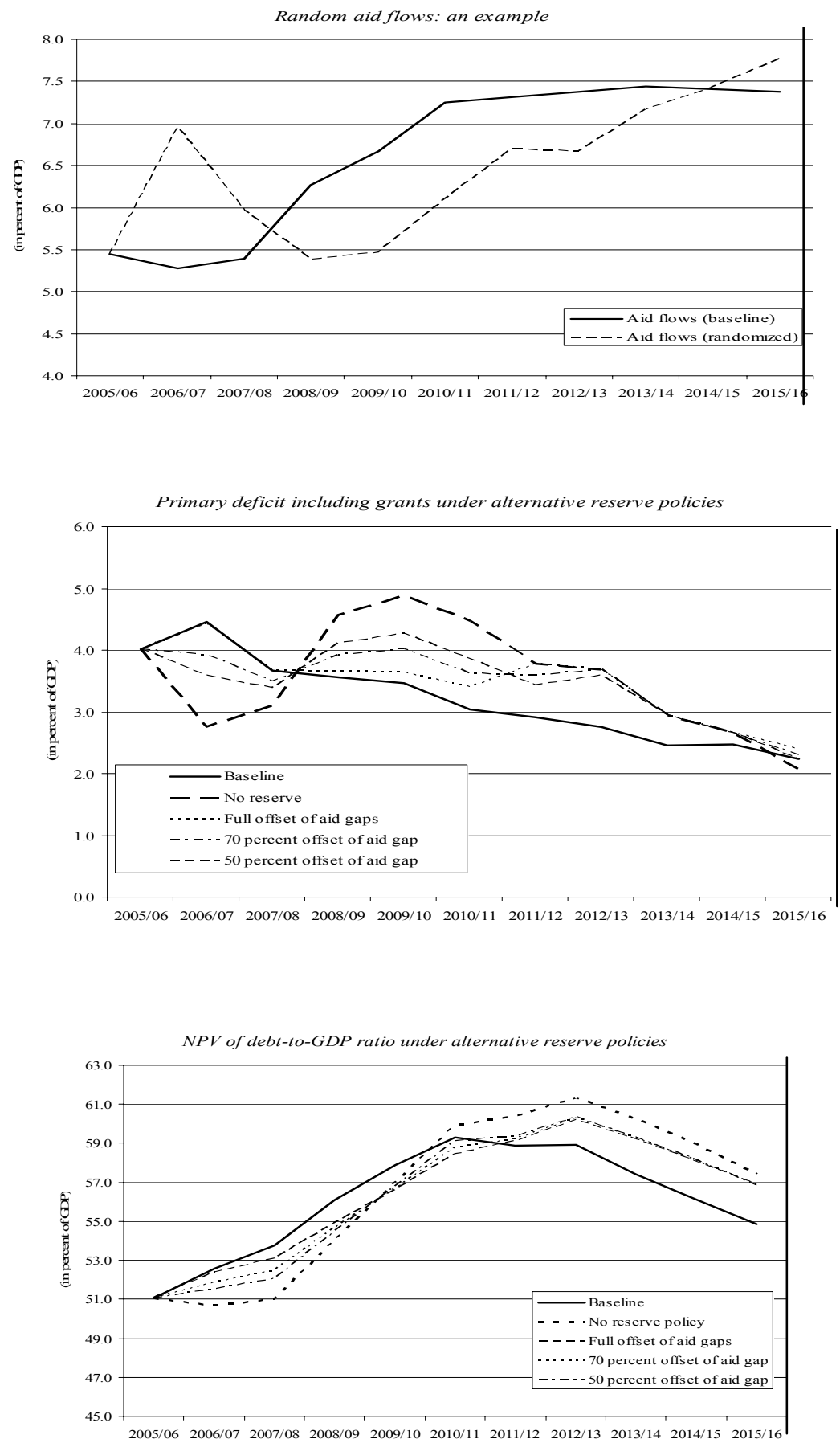

Source: IMF staff estimates. 